\title{
Lanternfish larvae from the Agulhas current (SW Indian Ocean)*
}

\author{
M.P. OLIVAR ${ }^{1 \dagger}$, H.G. MOSER ${ }^{2}$ and L.E. BECKLEY ${ }^{3}$ \\ ${ }^{1}$ Institut de Ciències del Mar. CSIC. Passeig Joan de Borbó s/n. Barcelona. Spain. \\ Fax: 349322173 40. email: polivar@icm.csic.es \\ ${ }^{2}$ Southwest Fisheries Science Center. P.O. Box 271. La Jolla, CA 92038-0271. USA. \\ ${ }^{3}$ Oceanographic Research Institute. P.O. Box 10712. Marine Parade. Durban 4056. South Africa.
}

\begin{abstract}
SUMMARY: This paper is presented as a guide to assist in identifying larval stages of lanternfish (family Myctophidae) of the Agulhas Current region. The work is based on the larvae collected during three cruises conducted off the eastern coast of South Africa from $29^{\circ} \mathrm{S}$ to $34^{\circ} \mathrm{S}$ in 1990 and 1991 . The larval distributions obtained from these surveys are summarised briefly. Generally, only literature citations are given for species of the region whose larvae have been described previously. Descriptions are limited to those species for which complete larval development have not been published previously and to those species not known to spawn in the region, to compare larval features with those from regions where the species is known to spawn (i.e., Benthosema fibulatum, B. pterotum, Hygophum proximum, Lampadena luminosa, Myctophum selenops, Notoscopelus caudispinosus and Triphoturus nigrescens). Also, diagnostic characters and illustrations are presented for species which may be difficult to identify in some developmental stages, particularly the early larval stages (i.e., Benthosema suborbitale, Bolinichthys spp., Ceratoscopelus townsendi, Diogenichthys panurgus, Myctophum phengodes, Lobianchia dofleini, L. gemellarii and Scopelopsis multipunctatus).
\end{abstract}

Key words: Myctophidae. Fish larvae. SW Indian Ocean. Diagnosis early larval stages.

\section{INTRODUCTION}

Lanternfish are an important component of the mesopelagic and bathypelagic fauna of the Agulhas current waters (Hulley 1984a) (Table 1) and their larvae constitute from 10 to $50 \%$ of the total fish larvae collected during a series of research cruises conducted off the eastern coast of South Africa from $29^{\circ} \mathrm{S}$ to $34^{\circ} \mathrm{S}$ in 1990 and 1991 (Beckley and Van Ballegooyen 1992). Temporal and spatial patterns of distribution of these larvae were discussed by Olivar and Beckley (1994a). Identification was difficult because of the similarity of many of the small larvae collected during these cruises, especially of the early

Corresponding author

*Received November 30, 1998. Accepted May 11, 1999. developmental stages. Nevertheless, larvae of 43 species belonging to the family Myctophidae were differentiated from these cruises. Larvae of several lanternfish species were identified for the first time and were described in separate papers (Olivar and Beckley, 1994b, 1995, 1997; Olivar and Palomera, 1994).

This paper is presented as an overall guide to the identification of lanternfish larval stages of the Agulhas Current. For identification to family level we direct the reader to general monographs, especially those that include Indian and Pacific Ocean species (Russell 1976; Miller et al. 1979; Fahay 1983; Leis and Rennis 1983; Moser et al. 1984; Ozawa 1986; Okiyama 1988; Leis and Trnski 1989; Matarese et al. 1986; Olivar and Fortuño 1991; Moser 1996; Neira et al. 1998). The general features 
TABLE 1. - Myctophid species recorded as adults in the Agulhas current (Hulley, 1984a) and presence of their larvae in the SE coast of South Africa (Olivar and Beckley, 1994a).

\begin{tabular}{|c|c|c|c|c|c|}
\hline SPECIES & ADULTS & LARVAE & SPECIES & ADULTS & LARVAE \\
\hline Benthosema fibulatum & + & + & Lampadena luminosa & + & + \\
\hline Benthosema pterotum & - & + & Lampadena notialis & + & - \\
\hline Benthosema suborbitale & + & + & Lampadena speculigera & + & - \\
\hline Bolinichthys indicus & + & - & Lampanyctus achirus & + & + \\
\hline Bolinichthys supralateralis & + & - & Lampanyctus alatus & + & + \\
\hline Ceratoscopelus townsendi & + & + & Lampanyctus ater & + & + \\
\hline Diaphus aliciae & + & - & Lampanyctus australis & + & - \\
\hline Diaphus brachycepahus & + & + & Lampanyctus festivus & + & - \\
\hline Diaphus diadematus & + & + & Lampanyctus lepidolychnus & + & + \\
\hline Diaphus effulgens & + & - & Lampanyctus nobilis & + & + \\
\hline Diaphus garmani & + & - & Lampanyctus pusillus & + & + \\
\hline Diaphus hudsoni & + & - & Lampanyctus turneri & + & - \\
\hline Diaphus jenseni & + & - & Lobianchia dofleini & + & + \\
\hline Diaphus lucidus & + & + & Lobianchia gemellarii & + & + \\
\hline Diaphus luetken & + & - & Myctophum asperum & + & + \\
\hline Diaphus metapoclampus & + & - & Myctophum aurolaternatum & + & - \\
\hline Diaphus mollis & + & + & Myctophum nitidulum & + & + \\
\hline Diaphus nielseni & + & - & Myctophum obtusirostre & + & - \\
\hline Diaphus parri & + & - & Myctophum phengodes & + & + \\
\hline Diaphus perspicillatus & + & - & Myctophum selenops & - & + \\
\hline Diaphus problematicus & + & - & Myctophum spinosum & + & + \\
\hline Diaphus richardsoni & + & - & Notolychnus valdiviae & + & + \\
\hline Diaphus splendidus & + & - & Notoscopelus caudispinosus & + & + \\
\hline Diogenichthys atlanticus & + & + & Notoscopelus resplendens & + & + \\
\hline Diogenichthys panurgus & + & + & Scopelopsis multipunctatus & + & + \\
\hline Electrona rissoi & + & - & Symbolophorus barnardi & + & + \\
\hline Gonichthys barnesi & + & - & Symbolophorus evermanni & + & + \\
\hline Hygophum hanseni & + & - & Taaningichthys bathyphilus & + & - \\
\hline Hygophum hygomii & + & + & Triphoturus nigrescens & + & + \\
\hline Hygорһит ргохітит & + & + & & & \\
\hline
\end{tabular}

of each genus are treated briefly, since they have been described extensively by Moser and Ahlstrom (1970; 1972; 1974; 1996) and Moser et al. (1984). For the subfamily Myctophinae information on the main sources of larval descriptions and new data on larval development are presented for several species belonging to Benthosema, Diogenichthys, Hygophum, Myctophum and Symbolophorus. Within Lampanyctinae similar kinds of information are given for several species of Bolinichthys, Ceratoscopelus, Diaphus, Lampadena, Lampanyctus, Lobianchia, Notolychnus, Notoscopelus, Scopelopsis and Triphoturus.

In general, diagnostic characters for larval identification and illustrations of larvae collected in the area are included. More detailed descriptions of larval development are given for those species for which complete larval development series have not been previously published (e.g. Lampadena luminosa). For those species not known to spawn in the region we include brief descriptions of morphology, pigmentation, and photophore development to compare larval features with those from regions where the species are known to spawn (Benthosema fibulatum, B. pterotum, Hygophum proximum, Myctophum selenops, Notoscopelus caudispinosus, Triphoturus nigrescens). A section on species comparisons is included for species whose larvae are especially difficult to identify.

A reference collection of the lanternfish larvae collected in the Agulhas current region during these cruises is deposited in the Ichthyoplankton Collection of the Institut de Ciències del Mar of Barcelona (ICICMB).

\section{MATERIAL AND METHODS}

The larvae examined in this study came from three cruises conducted in May/June 1990, October 1990, and February 1991 off the east coast of South Africa (Agulhas Current region). Ichthyoplankton samples were obtained with a Bongo net fitted with $0.5 \mathrm{~mm}$ mesh hauled obliquely from $80 \mathrm{~m}$ to the surface, where bottom depth permitted. The stations were arranged in a series of nine transects perpendicular to the coastline at isobaths of $50 \mathrm{~m}, 100 \mathrm{~m}$, $500 \mathrm{~m}$ and $2000 \mathrm{~m}$.

Larvae were preserved in 5\% buffered saline formalin and measurements were made at least six months after collection and fixation at sea. Measurements were performed to an accuracy of $0.1 \mathrm{~mm}$. Lar- 
val length refers to body length (BL), the distance along the midline of the body from the tip of the snout to the tip of the notochord in preflexion and flexion larvae, and to the posterior margin of the hypural elements in postflexion stages. Other measures recorded were: preanal length (PAL), the distance along the midline of the body from the tip of the snout to the vent; head length, the distance from the tip of the snout to the posterior margin of the cleithrum; body depth at pectoral (BDP), depth of the body at the base of the pectoral fin and eye diameter (ED).

The following photophore terminology is based on Moser and Ahlstrom (1972) and Fujii (1984): $\mathrm{Br}_{2}$, second branchiostegal photophore; Dn, dorsonasal photophore; Op, opercular photophore; PO, pectoral photophores, a ventral series of photophores situated between the opercle and the bases of the pelvic fin; PVO, subpectoral photophores, located between the opercle and the pectoral fin; AOa, anterior anal photophores, series located on each side of the anal fin base; Vn, ventronasal photophore; PLO, suprapectoral photophore.

Larval nomenclature used in this paper follows Kendall et al. (1984). Abbreviations for meristic characters were the following: $\mathrm{D}$, number of dorsal fin rays; A, number of anal fin rays; $P$, number of pectoral fin rays, GR, number of gill rakers. Information on adult meristic characters came from the following papers: Nafpaktitis and Nafpaktitis (1969); Wisner (1976); Nafpaktitis et al. (1977); Nafpaktitis (1978); Hulley (1981, 1984a, 1984b, 1986); Tsokur (1982); Bourret (1985); Moser and Ahlstrom (1996).
Within the descriptions we give information on adult distributions in the area, this information was obtained from Hulley's (1984a) study, based on adult lanternfishes obtained during 5 cruises off the east coast of South Africa from $27^{\circ} \mathrm{S}$ to $34^{\circ} \mathrm{S}$

\section{DESCRIPTIONS OF LARVAE}

\section{Subfamily MyctophinAE}

Benthosema fibulatum (Gilbert and Cramer, 1897) (Fig. 1)

The species has a tropical subtropical distribution, but a few immature adults have been collected in the region (Hulley 1984a). Counts: D 12-14, A 18-20, P 14-17, GR 6-7+1+12-16, vertebrae 3132 .

Larvae appeared on all three cruises. Spatial distribution extended from north to south and from coastal stations $(50 \mathrm{~m})$ to the most offshore ones $(2000 \mathrm{~m})$. Total larvae examined: $253,3.0-12.5 \mathrm{~mm}$ BL. Identification was based on the descriptions of Moser and Ahlstrom (1974); Pertseva-Ostroumova (1974) and Ozawa (1986).

\section{Morphology}

Body relatively slender (BDP $<20 \% \mathrm{BL}$ in preflexion and flexion stages); gut extending to the midpoint of the body; eyes slightly ovate; notochord flexion begins around $5.0 \mathrm{~mm}$ and the urostyle is flexed at $6.0 \mathrm{~mm}$.
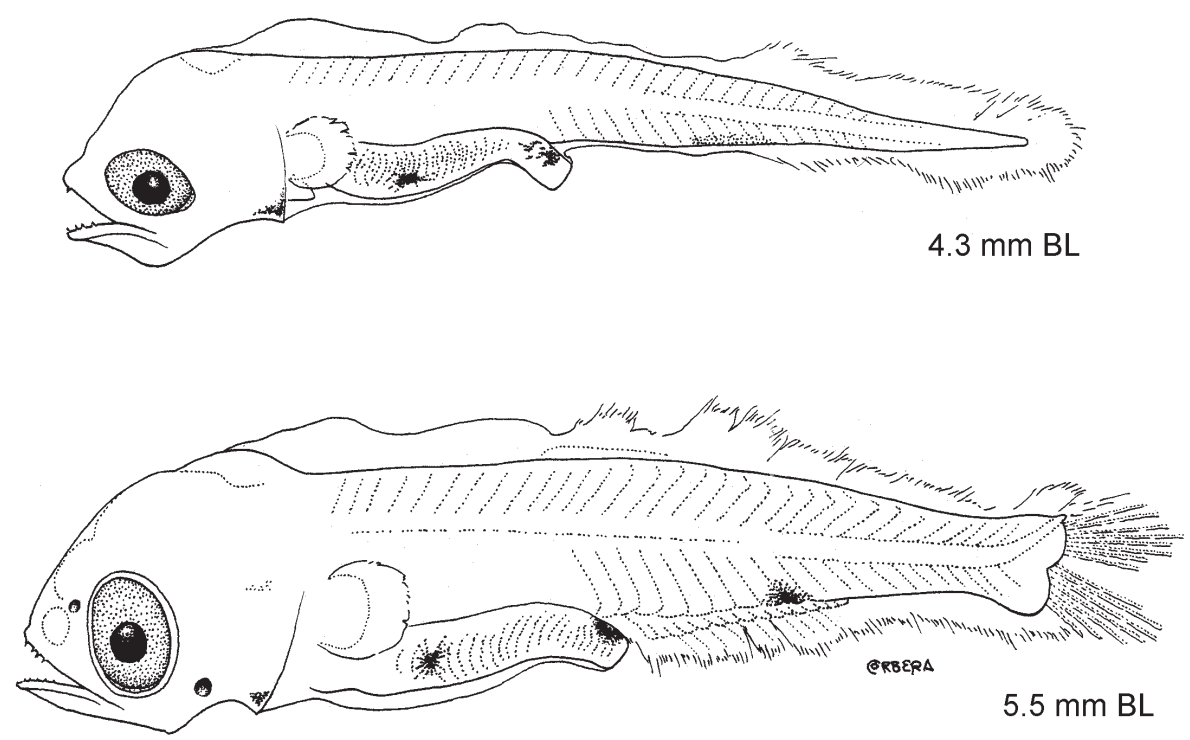

FIG. 1. - Developmental stages of Benthosema fibulatum from the Agulhas current region: $4.3 \mathrm{~mm}$ and $5.5 \mathrm{~mm}$. ICICMB 170/AGU. 

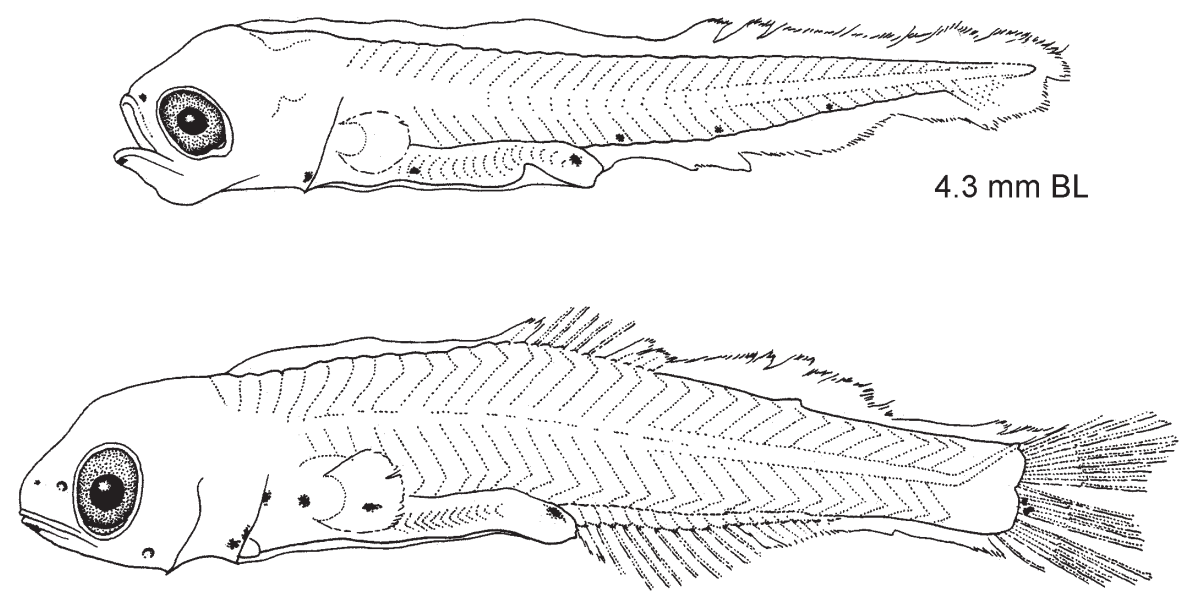

$6.9 \mathrm{~mm} \mathrm{BL}$

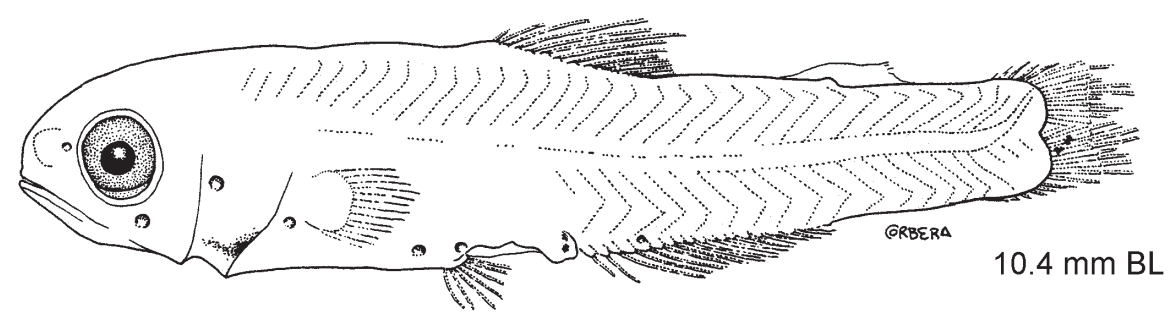

FIG. 2. - Developmental stages of Benthosema pterotum from the Agulhas current region: $4.3 \mathrm{~mm}, 6.9 \mathrm{~mm}$ and 10.4 mm. ICICMB 172/AGU.

\section{Pigmentation}

Blotch in ventral midline anterior to the cleithral symphysis; one stellate melanophore on the lateral wall of the gut midway between the anus and the cleithral symphysis, and another one on the free terminal section of the gut; in larvae $<4 \mathrm{~mm}$, three or four postanal melanophores on the ventral midline of the body, later coalescing to one; embedded in the otic region; in some larvae $>7.5 \mathrm{~mm} \mathrm{BL}$ one melanophore is present on the ventral margin of the caudal peduncle.

\section{Photophore development}

Dn appears at 5-6 $\mathrm{mm} ; \mathrm{PO}_{5}$ at $6 \mathrm{~mm}$.

\section{Benthosema pterotum (Alcock, 1891)}

(Fig. 2)

No adults of the species have been reported off the eastern coast of South Africa (Hulley 1984a; 1986). This is a common species of the Arabian Sea and the nearest recorded specimens were from Mozambique waters (Dalpadado, 1988). Counts: D 12-14, A 19-22, P 12-14, GR 6-9+1+14-19, myomeres $12-14$ to $18-20$.
Larvae of $B$. pterotum were present on all three cruises, with highest abundance in the May/June cruise. They were collected mainly over the shelf, along the entire coast, with highest abundances at the $50 \mathrm{~m}$ stations. Total larvae examined: 475, 2.4$10.4 \mathrm{~mm} \mathrm{BL}$. Identification was based on the descriptions of Moser and Ahlstrom (1974) (B. panamense); Tsokur (1982) and Ozawa (1986).

\section{Morphology}

Body moderately slender (BDP 14-19\% BL); gut extends to slightly behind the midpoint of the body (PAL 52-57\% BL); notochord flexion begins around $5.0 \mathrm{~mm}$ and the urostyle is flexed at $6.0 \mathrm{~mm}$.

\section{Pigmentation}

Blotch anterior to the cleithral symphysis present in all larval stages; a melanophore on the lateral wall of the gut and another one on the free terminal section of the gut; a melanophore on the tip of the lower jaw, and a pair on the snout; all above melanophores indistinct or absent in larvae $>10 \mathrm{~mm}$; three or four melanophores on the midventral line of the tail present in very early larvae; these coalesce to one in larvae 4.5 to $5.5 \mathrm{~mm} \mathrm{BL}$, located $c a .7$ myomeres pos- 


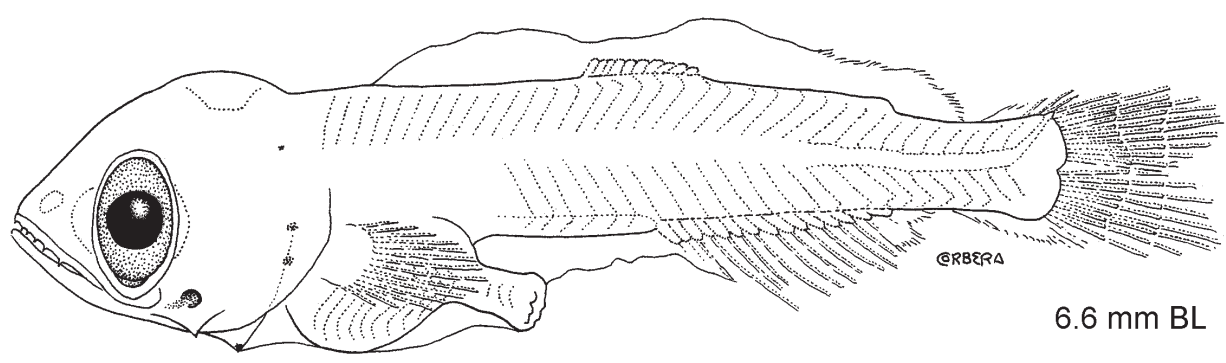

FIG. 3. - Larva of Benthosema suborbitale from the Agulhas current region: $6.6 \mathrm{~mm}$. ICICMB 174/AGU.

terior to the anus; this melanophore seldom visible in larger larvae.

\section{Photophore development}

$\mathrm{Br}_{2}$ beginning to form at $5.0 \mathrm{~mm} ; \mathrm{Br}_{2}$ and $\mathrm{Dn}$ begin forming at $c a .5 .7 \mathrm{~mm} ; \mathrm{PO}_{5}$ at $8.4 \mathrm{~mm}$.

\section{Comparative remarks}

No pigmentation present on the tip of the lower jaw and snout in B. fibulatum, but present in B. pterotum. Melanophores large and often stellate in $B$. fibulatum and small and inconspicuous in B. pterotum. In B. pterotum, postanal melanophore on the ventral midline of the body disappears in larvae $>6 \mathrm{~mm}$, but is still present in transforming larvae of $B$. fibulatum. Body slightly more slender in $B$. pterotum than in $B$. fibulatum. Photophores larger in B. fibulatum. Order of photophore development differs between the two species (see table 1 of Moser and Ahlstrom 1974). $\mathrm{Br}_{2}$, Dn and $\mathrm{PO}_{5}$ appear earlier in B. fibulatum than in B. pterotum, followed by $\mathrm{PVO}_{1}$ and $\mathrm{Op}_{2}$ in $B$. pterotum and $\mathrm{PO}_{1}$ and $\mathrm{AOa}_{1}$ in B. fibulatum.

Eyes less narrow in Benthosema than in Hygophum larvae. Dorsal fin develops earlier in Benthosema than in Hygophum. Photophores (in addition to $\mathrm{Br}_{2}$ ) develop earlier in Benthosema than in Hygophum.

\section{Benthosema suborbitale (Gilbert, 1913)} (Fig. 3)

Adults of this species have a broadly tropical distribution, they were the most common Benthose$m a$ found in the area by Hulley (1984a). Counts: D 11-14, A 16-19, P 12-15, vertebrae 33-35.

Larvae of B. suborbitale were present on all cruises. Their abundances were never very high (maximum of 49 larvae under $10 \mathrm{~m}^{2}$ ), but they occurred frequently throughout the region, less com- monly at the most offshore stations. Total larvae examined: 65 , from preflexion to the end of flexion stages. They were identified through the descriptions of Moser and Ahlstrom (1974, 1996), Pertseva-Ostroumova (1974), Badcock and Merret (1976), Shiganova (1977) and Ozawa (1986).

\section{Diagnostic characters}

Larvae of B. suborbitale are easily separated from the other two species of the genus discussed above by morphology (mainly head and gut region), the pronounced space between the anus and the anal fin and reduced pigmentation. The gut is not straight as in the other two species. The number of myomeres is greater than in the other two species. Also, photophore development is different, $\mathrm{Br}_{2}, \mathrm{PO}_{1}$, $\mathrm{PO}_{2}$ are the first to appear.

The early presence of $\mathrm{Br}_{2}$ (at ca. $3.0 \mathrm{~mm} \mathrm{BL}$ ), the shape of this photophore, the pigmentation on the cleithral symphysis, the shape of the gut and the wide space between anus and anal fin differentiate these larvae from those of Electrona rissoi, a species not found among the larvae collected in the present surveys, but present as adults in the southwest Indian Ocean (Hulley 1986).

\section{Diogenichthys atlanticus (Tåning, 1928) and D. panurgus Bolin, 1946 (Fig. 4)}

Two species of this genus $D$. atlanticus and $D$. panurgus have been recorded in the Agulhas Current region (Hulley 1984a). Counts for D. atlanticus: D 10-12, A 14-18, P 10-14, GR 2+1+9-12, vertebrae 31-35. Counts for D. panurgus: D 10-12, A 15-17, P 10-11, GR 2-3+1+8-10.

Larvae of both species appeared on the three cruises, but $D$. panurgus was more abundant in May/June 1990. Both species were more abundant north of East London. Total D. atlanticus larvae 


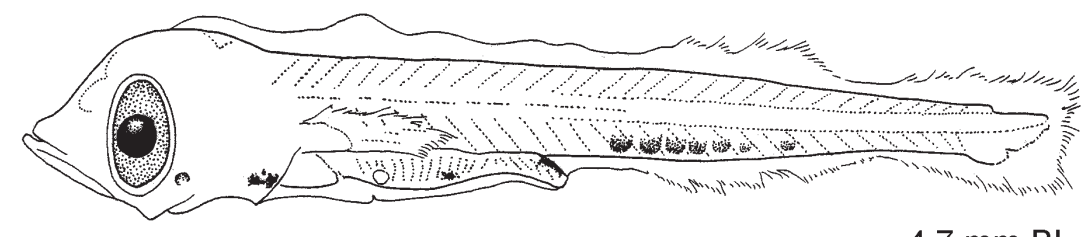

$4.7 \mathrm{~mm} \mathrm{BL}$

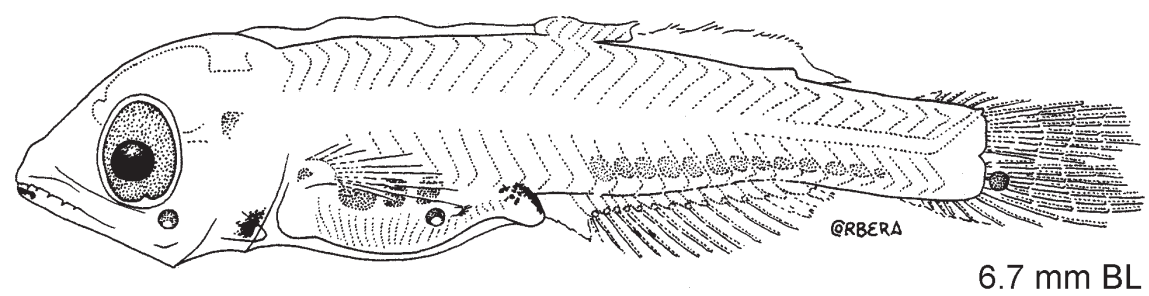

FIG. 4. - Developmental stages of Diogenichthys panurgus from the Agulhas current region: $4.7 \mathrm{~mm}$ and 6.7 mm. ICICMB 176/AGU.

examined: 52, from preflexion to postflexion stages. The complete larval series of development (from larvae of $3.6 \mathrm{~mm}$ to juveniles of $16.0 \mathrm{~mm}$ ) was described by Moser and Ahlstrom (1970). Other larval descriptions have been published by PertsevaOstroumova (1974); Shiganova (1977) and Ozawa (1986). Total D. panurgus larvae examined: 265, ca. 3.0 to $9 \mathrm{~mm}$ BL. Larvae were identified using the description published by Pertseva-Ostroumova (1974).

\section{Diagnostic characters}

Both species are easily differentiated when $>5$ $\mathrm{mm}$ by the presence of a barbel at the symphysis of the lower jaw in $D$. atlanticus, a feature absent in $D$. panurgus. Smaller stages may be differentiated by the presence of pigmentation at the symphysis of the lower jaw in D. panurgus, and its absence in $D$. atlanticus. Furthermore, in larvae $<5 \mathrm{~mm}$ the $\mathrm{Br}_{2}$ photophore is already developed in D. panurgus, but appears later in D. atlanticus.

\section{Genus Hygophum}

Adults of three species of the genus Hygophum have been collected in the Agulhas Current region: $H$. hygomii a subtropical species, $H$. hanseni a "South Temperate" species (Hulley, 1981), and $H$. proximum a tropical species. $H$. hygomii is the most abundant, and only a few immature individuals of the other two species were reported by Hulley (1984a).

\section{H. hygomii (Lütken, 1892) and $\boldsymbol{H}$. proximum Bekker, 1965 (Fig. 5)}

Two types were present among the larvae examined. The most abundant corresponded to Hygophum hygomii. Total larvae examined: 1668, 2.5$13.5 \mathrm{~mm}$ BL. These larvae were described by Olivar and Palomera (1994). The other Hygophum larvae belonged to Hygophum proximum. Total larvae examined: 33, 3.0-10.8 mm BL. Counts for Hygophum hygomii: D 13-15, A 20-23, P 14-17, GR 46+1+13-16, vertebrae 36-37. Counts for Hygophum proximum: D 12-14, A 18-21, P 13-15, GR 3$5+1+11-14$, vertebrae 36 .

Larvae of $H$. hygomii occurred along the entire survey area except at the southern inshore sector. They were especially abundant in the May/June 1990 cruise. H. proximum larvae also occurred on the three cruises, but were more common during the February 1991 cruise and were mostly concentrated in the northern sector. A number of descriptions are available for larvae of $H$. hygomii and $H$. proximum (Moser and Ahlstrom 1974, 1996; PertsevaOstroumova 1974; Shiganova 1977; Berdar and Cavaliere 1979; Ozawa 1986; Olivar and Palomera 1994; Moser and Ahlstrom 1996). The diagnostic characters of $H$. proximum larvae that differentiate them from $H$. hygomii are given below.

\section{Morphology}

Slender body in preflexion and flexion stages (BDP $<20 \%$ BL), and moderately slender in post- 

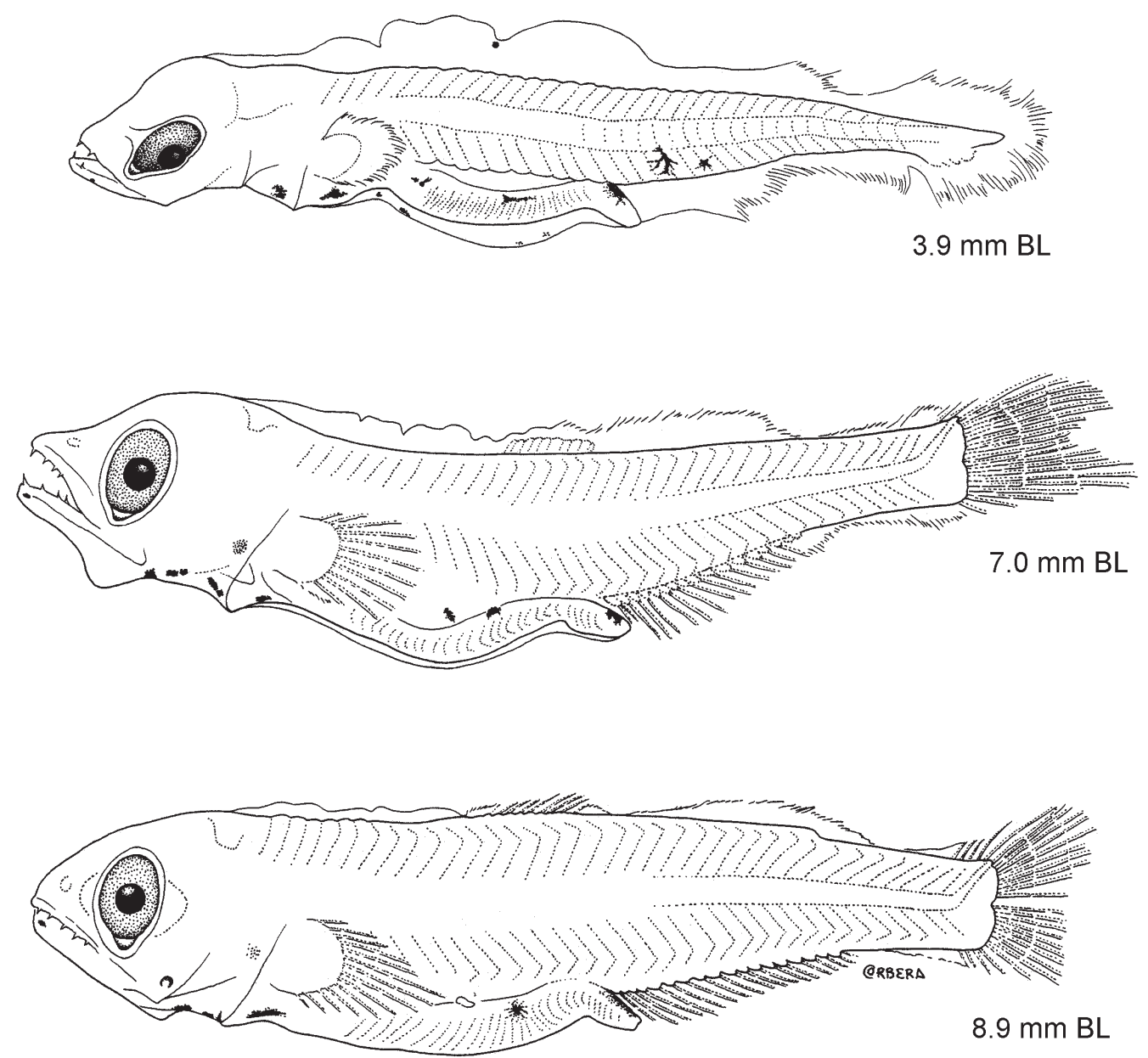

FIG. 5. - Developmental stages of Hygophum proximum from the Agulhas current region: $3.9 \mathrm{~mm}, 7.0$ and $8.9 \mathrm{~mm}$. ICICMB 178/AGU.

flexion larvae (BDP $<24 \%$ of BL in larvae of 11 $\mathrm{mm}$ ); gut straighter and preanal length greater in $H$. proximum $(>60 \% \mathrm{BL}$ ) than in $H$. hygomii (BDP $<59 \% \mathrm{BL}$ ); in H. hygomii the dorsal fin extends posterior to the anus, while in $H$. proximum the anus is below the dorsal fin insertion; notochord flexion begins around $5.5 \mathrm{~mm}$ and the urostyle is flexed at $6.5 \mathrm{~mm}$.

\section{Pigmentation}

The pigmentation pattern is a useful character in the identification of preflexion and flexion stages. $H$. proximum larvae have one or two ventral tail melanophores near the anus (ca. 2-3 myomeres after the anus), whereas $H$. hygomii larvae have only one stellate melanophore 6-8 myomeres posterior to the anus; no pigment on pectoral fin rays in $H$. proximum, whereas melanophores scattered on pectoral rays in $H$. hygomii; a small melanophore at base of caudal fin in some flexion larvae of $H$. proximum, this pigmentation never present in $H$. hygomii larvae.

\section{Genus Myctophum}

Table 2 lists adults of this genus reported by Hulley $(1984 a$; 1986) in the SW Indian Ocean. Larval morphology and pigmentation pattern of some Myctophum species are distinctive enough to allow relatively easy identification (see diagnostic characters listed in Table 2).

\section{Myctophum asperum Richardson, 1845}

Counts: D 10-14, A 16-20, P 12-16, GR 3-5+1+9-12.

Two larvae of this species ( $c a .3 \mathrm{~mm} \mathrm{BL}$ ) were collected in May/June 1990 and another one in February 1991 (4.4 mm BL). They matched the descriptions given by Moser and Ahlstrom (1974); Pertseva-Ostroumova (1974) and Ozawa (1986). 
TABLE 2. - Main pigmentation and morphological features useful to differentiate larvae of the Myctophum species that may occur in the Agulhas current region.

\begin{tabular}{|c|c|c|c|c|c|c|}
\hline & Tail & Caudal & $\begin{array}{l}\text { PIGMENTATION } \\
\text { Anterior to dorsal fin }\end{array}$ & Pectoral bases & Pectoral rays & Above anus \\
\hline M. asperum & + & + & + & + & + & + \\
\hline M. aurolaternatum & + & - & - & - & - & + \\
\hline M. nitidulum & + & - & - & + & + & + \\
\hline M. obtusirostre & - & - & - & - & - & - \\
\hline M. phengodes & - & - & - & + & + & - \\
\hline M. selenops & - & - & - & + & + & - \\
\hline \multirow[t]{3}{*}{ M. spinosum } & + & + & + & - & - & + \\
\hline & \multicolumn{5}{|c|}{$\begin{array}{r}\text { MORPHOLOGY } \\
\text { MORH }\end{array}$} & \multirow[b]{2}{*}{$\mathrm{Br}_{2}$} \\
\hline & $\mathrm{BDP} / \mathrm{BL}$ & & Eyes & Gut & & \\
\hline M. asperum & $20-40 \%$ & \multicolumn{2}{|r|}{ sessile and not very narrow } & \multicolumn{2}{|c|}{ deep } & $7 \mathrm{~mm}$ \\
\hline M. aurolaternatum & $<10 \%$ & \multirow{2}{*}{\multicolumn{2}{|c|}{ stalked and narrow }} & \multicolumn{2}{|c|}{ straight } & $>20 \mathrm{~mm}$ \\
\hline M. nitidulum & $15-30 \%$ & & & & $8 \mathrm{~mm}$ \\
\hline M. obtusirostre & $20-40 \%$ & \multicolumn{2}{|r|}{$\begin{array}{l}\text { stalked and narrow } \\
\text { sessile and not very narrow }\end{array}$} & \multicolumn{2}{|c|}{ deep } & $4.5 \mathrm{~mm}$ \\
\hline M. phengodes & $20-30 \%$ & \multicolumn{2}{|r|}{ sessile and not very narrow } & \multirow{2}{*}{\multicolumn{2}{|c|}{ relatively straight }} & $6.5 \mathrm{~mm}$ \\
\hline M. selenops & $20-40 \%$ & \multicolumn{2}{|r|}{ sessile and narrow } & \multirow{2}{*}{\multicolumn{2}{|c|}{$\begin{array}{l}\text { deep } \\
\text { relatively straight }\end{array}$}} & $5 \mathrm{~mm}$ \\
\hline M. spinosum & $20 \%$ & \multicolumn{2}{|r|}{$\begin{array}{l}\text { very prominent choroid } \\
\text { small and prominent choroid }\end{array}$} & & & $9 \mathrm{~mm}$ \\
\hline
\end{tabular}

\section{Myctophum nitidulum Garman, 1899}

Counts: D 12-14, A 18-21, P 12-15. GR 48+1+11-18.

Larvae belonging to this species occurred on the three cruises, mainly north of Mbashe and offshore of the $200 \mathrm{~m}$ isobath. Total larvae examined: 31, 3.5$10.4 \mathrm{~mm}$ BL. Larvae were similar to those described by Moser and Ahlstrom (1974, 1996); PertsevaOstroumova (1974) and Ozawa (1986).

\section{Myctophum phengodes (Lütken, 1892)}

(Fig. 6)

Counts: D 12-14, A 20-22, P 15-17, GR 7-8+1+16-18. Total larvae examined: $13,4.5-6.5 \mathrm{~mm}$ BL. They were collected during the October 1990 and February 1991 cruises at stations located along the 500 and $2000 \mathrm{~m}$ isobaths. Identification of Agulhas larvae was based on the $9.8 \mathrm{~mm}$ larva described by Moser and Ahlstrom (1974).
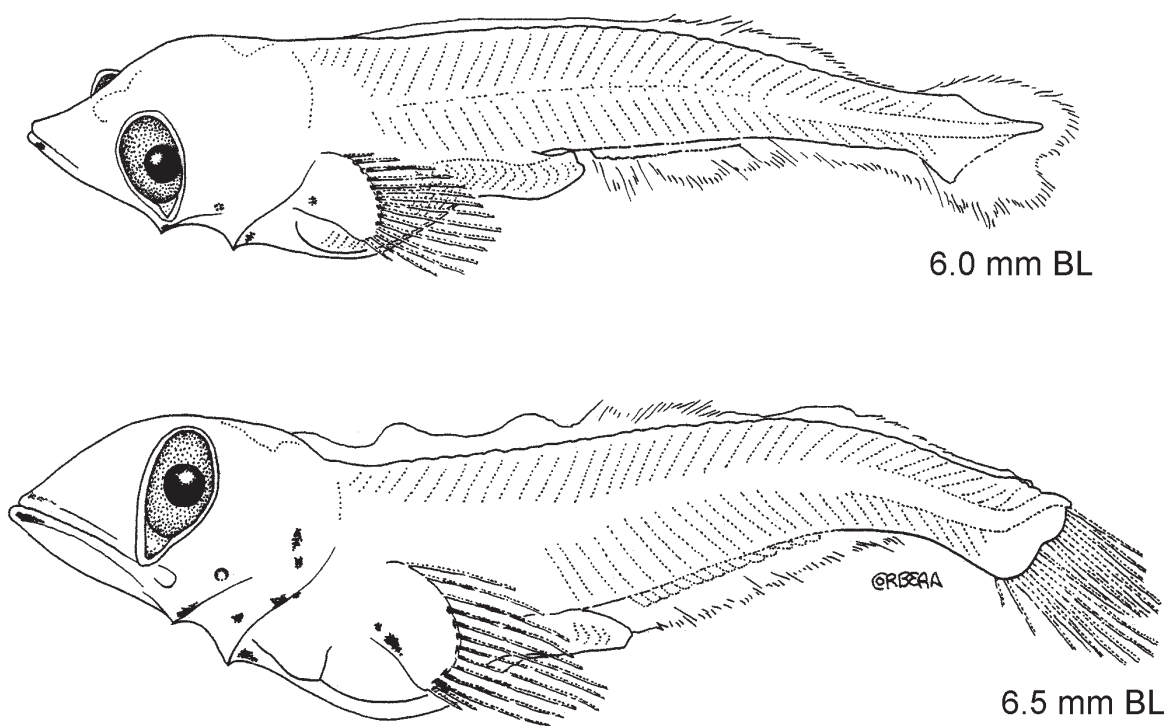

FIG. 6. - Developmental stages of Myctophum phengodes from the Agulhas current region: $6.0 \mathrm{~mm}$ and $6.5 \mathrm{~mm}$. ICICMB 179/AGU. 

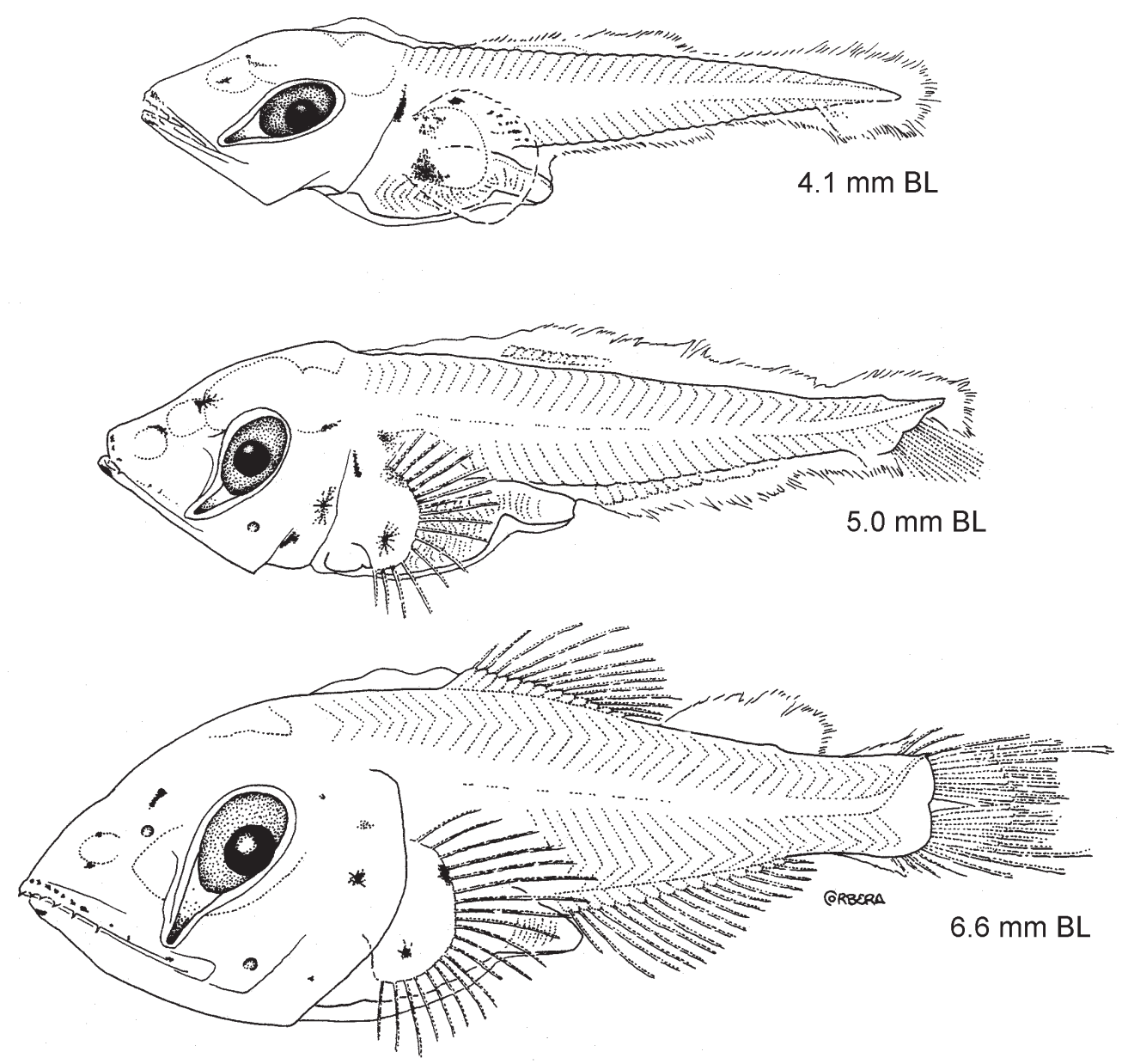

FIG. 7. - Developmental stages of Myctophum selenops from the Agulhas current region: $4.1 \mathrm{~mm}, 5.0 \mathrm{~mm}$ and 6.6 mm. ICICMB 181/AGU.

\section{Diagnostic characters}

Useful characters for species identification are the presence of melanophores at the margin of the pectoral fin base and lack of other larval pigmentation.

\section{Myctophum selenops Tåning, 1928}

(Fig. 7)

No adults of this species were reported by Hulley (1984a) during the Meiring Naude cruises in this same area, but the species has been found at southern localities associated with Agulhas waters (Hulley 1981; 1986). Counts: D 12-14, A 17-19, P 15-18, GR 6-7+1+14-17.

This was the most common Myctophum larva collected on the three cruises. They occurred in the study region during the three cruises, with highest abundances in May/June 1990. Total larvae examined: 191, 3.0-7.2 mm BL. Identification based on the description of a $7.8 \mathrm{~mm}$ postflexion larva in Moser and Ahlstrom (1974).

\section{Morphology}

The anterior region of the body prominent from early stages; snout pointed and head relatively large and deep; relative head length increases as development progresses (31-40\% of BL); body relatively deep at pectoral, BDP increases from 23\% of $\mathrm{BL}$ in preflexion larvae to $37 \%$ of $\mathrm{BL}$ in $7.2 \mathrm{~mm}$ BL larvae; preanal length to the midpoint of the body in preflexion larvae (PAL $48 \%$ of BL) and to $>60 \%$ of BL at $7.2 \mathrm{~mm}$; eyes very narrow and have a prominent mass of choroid tissue. Notochord flexion begins at $c a .5 .0 \mathrm{~mm}$ and the urostyle is flexed at $6.0 \mathrm{~mm}$.

\section{Pigmentation}

No pigmentation present on tail; a single stellate melanophore present ventrally on trunk; a melanistic blotch located ventrally on base of the pectoral fin, and another one dorsally on inner side of the fin; another group of melanophores present on opercular margin. 


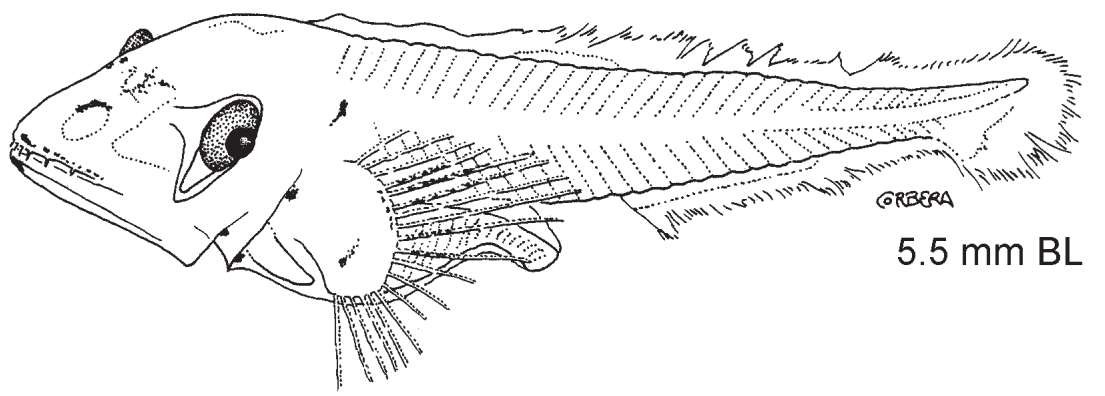

FIG. 8. - Larva of Myctophum sp. from the Agulhas current region: $5.5 \mathrm{~mm}$. ICICMB 183/AGU.

\section{Photophore development}

$\mathrm{Br}_{2}$ is already present in $4.5 \mathrm{~mm} \mathrm{BL}$ larvae; $\mathrm{Vn}$ appear at $c a .5 .9 \mathrm{~mm}$. No other photophores were present in the $7.2 \mathrm{~mm}$ larva.

\section{Myctophum spinosum (Steindachner, 1867)}

Counts: D 12-14, A 18-20, P 13-15, GR 5$8+1+12-18$.

Two larvae of this species appeared during May/June 1990 survey (3.4 and $5.3 \mathrm{~mm} \mathrm{BL}$ ) and three more larvae during the February 1991 cruise (6.1, 8.4 and $9 \mathrm{~mm} \mathrm{BL})$. These larvae were identified with the descriptions of Moser and Ahlstrom (1974); Pertseva-Ostroumaova (1974) and Ozawa (1986).

\section{Myctophum sp.}

(Fig. 8)

Seven larvae identified as Myctophum sp. occurred in the samples (from 4 to $5.5 \mathrm{~mm} \mathrm{BL}$ ). They resemble $M$. phengodes in their slight pigmen- tation. The main differences are the smaller eyes and the pigmentation between the eyes in these larvae.

\section{Genus Symbolophorus}

Two species of Symbolophorus have been reported in the Agulhas current region, the subtropical S. barnardi and the tropical S. evermanni, though no mature individuals of the latter have been found. Larvae of both species occurred in our samples. Olivar and Beckley (1994b) give a detailed description of them together with comparative comments on larvae of other Symbolophorus species that may occur around southern Africa (see summary in Table 3).

\section{SUBFAMILY LAMPANYCTINAE Genus Bolinichthys}

(Fig. 9)

Larvae of Bolinichthys indicus and B. supralateralis, the two species of this genus reported in the area (Hulley 1984a) are undescribed. A few larvae

TABLE 3. - Main pigmentation and morphological features useful to differentiate larvae of the Symbolophorus species that may occur in the Agulhas current region.

\begin{tabular}{|c|c|c|c|c|}
\hline & $\begin{array}{l}\text { Ventral midline } \\
\text { preflexion }\end{array}$ & $\begin{array}{l}\text { PIGMENTATION } \\
\text { Ventral midline } \\
\text { flexion- } 8.5 \mathrm{~mm}\end{array}$ & $\begin{array}{l}\text { Melanophores outlining } \\
\text { pectoral bases }\end{array}$ & Lateral gut \\
\hline S. barnardi & $>10$ melanophores & 8-10 melanophores & + & $>5$ \\
\hline S. boops & $>8$ melanophoes & 0-7 melanophores & + & $<5$ \\
\hline \multirow[t]{2}{*}{ S. evermanni } & $<7$ melanophores & $0-2$ & - & $<5$ \\
\hline & PAL/BL preflexion-flexion & $\begin{array}{l}\text { MORPHOLOGY } \\
\text { PAL/BL at } 8.5 \mathrm{~mm}\end{array}$ & Notochordal flexion & $\mathrm{Br}_{2}$ \\
\hline S. barnardi & $47-63 \%$ & $64 \%$ & $7-8 \mathrm{~mm}$ & Not before $9 \mathrm{~mm}$ \\
\hline S. boops & $46-59 \%$ & $59 \%$ & $6.5-7.5 \mathrm{~mm}$ & ca. $9 \mathrm{~mm}$ \\
\hline S. evermanii & $62-63 \%$ & $63 \%$ & $5.5-6.5 \mathrm{~mm}$ & $6.5-7 \mathrm{~mm}$ \\
\hline
\end{tabular}



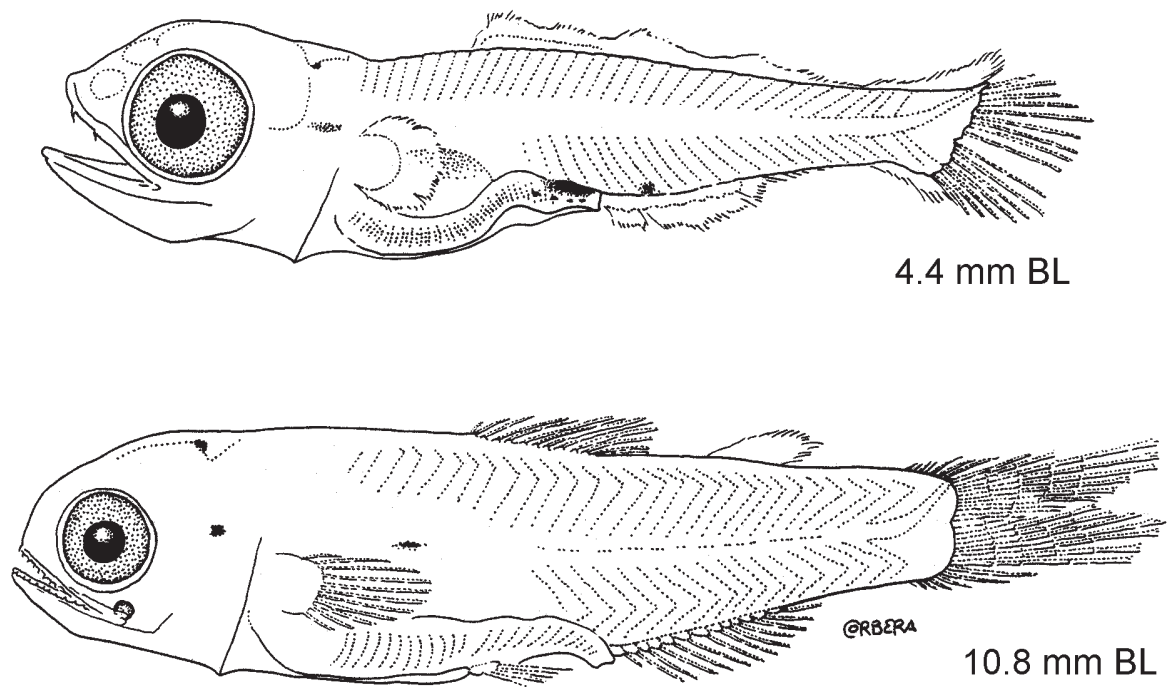

FIG. 9. - Developmental stages of Bolinichthys spp. from the Agulhas current region: $4.4 \mathrm{~mm}$ and 10.8 mm. ICICMB 184/AGU.

(19) belonging to this genus appeared in the surveys, the majority of them during the February 1991 cruise. Larval sizes ranged from 4.1 to $10.8 \mathrm{~mm}$ BL. We could not identify them to species nor sort them into more than one type.

\section{Diagnostic characters}

Larvae of this genus are characterised by large, round eyes, together with pigmentation above the brain and embedded in the otic region (Moser et al. 1984), and absence of pigmentation at the cleithral symphysis.

\section{Ceratoscopelus townsendi (Eigenmann and Eigenmann, 1889) (Fig. 10)}

This is the only species of the genus in the area. Counts: D 13-15, A 13-16, P 12-15, GR 3-5+1+8-11.

Larvae of $C$. townsendi were collected during the three cruises, mainly offshore of the $50 \mathrm{~m}$ isobath. Total larvae examined: 43, 3.0-13.7 mm BL. The main characters referred to in Miller et al. (1979); Moser et al. (1984) and Ozawa (1986) are useful in differentiating flexion and postflexion larvae from other species. Miller et al. (1979) described early

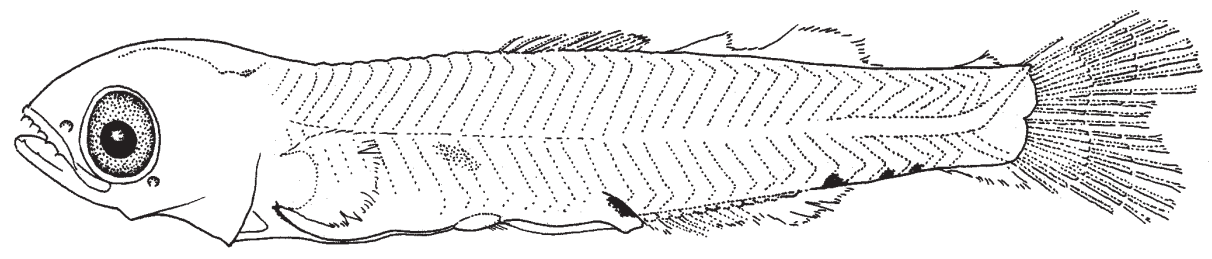

$7.4 \mathrm{~mm} \mathrm{BL}$

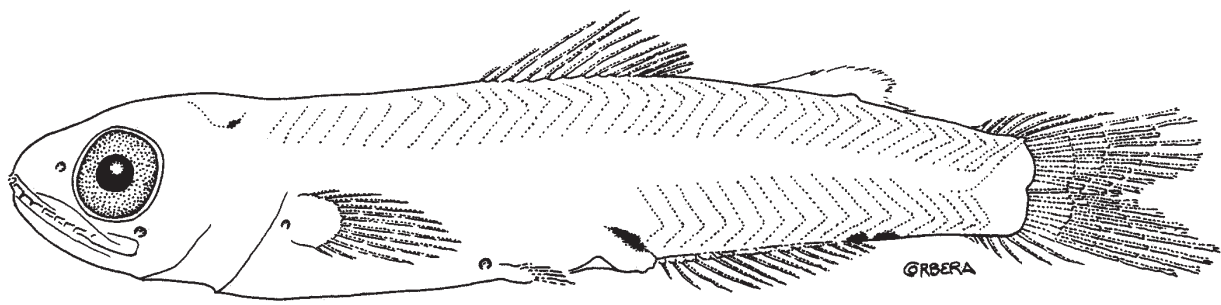

$12.1 \mathrm{~mm} \mathrm{BL}$

FIG. 10. - Developmental stages of Ceratoscopelus townsendi from the Agulhas current region: $7.4 \mathrm{~mm}$ and 12.1 mm. ICICMB 185/AGU. 

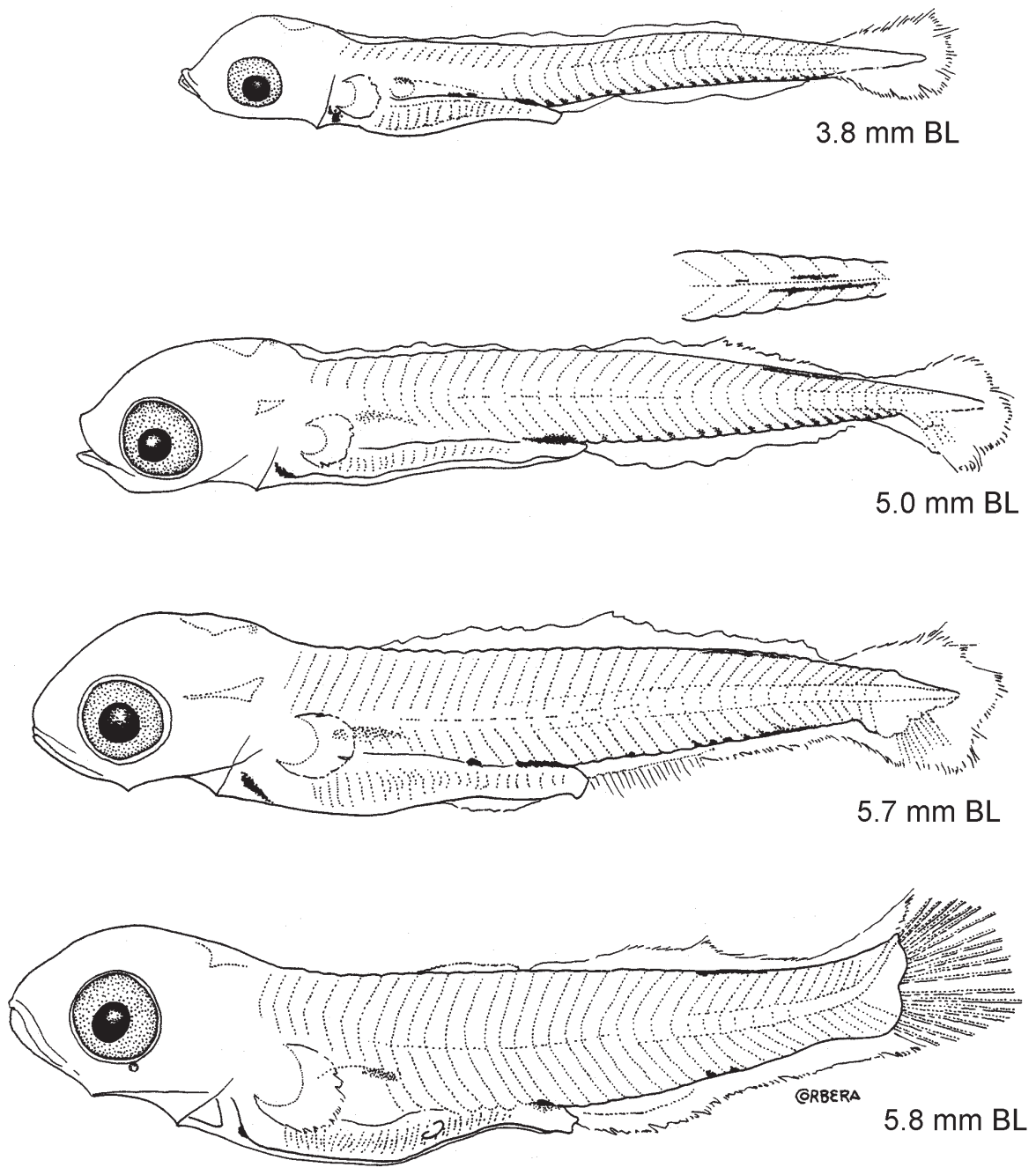

FIG. 11. - Preflexion and flexion developmental stages of Lampadena luminosa from the Agulhas current region: $3.8 \mathrm{~mm}$, dorsal and lateral view of a $5.0 \mathrm{~mm}$ larva, $5.7 \mathrm{~mm}$ and $5.8 \mathrm{~mm}$. ICICMB 187/AGU.

larvae from the mid-Pacific and Moser and Ahlstrom (1996) described the complete developmental series for larvae from the California Current region. We compare the main features of our larvae with these previous descriptions.

\section{Diagnostic characters}

Eyes slightly elliptical in early larvae; no pigmentation on the cleithral symphysis; a paired melanophore present at the anus; two to three melanophores on the midventral line of the body posterior to the anal fin; larger larvae of this species more rounded in cross-section (less compressed) than those of other species.

\section{Comparative remarks}

Differences with $B$. pterotum: No pigmentation on the cleithral symphysis in Ceratoscopelus; melanophores on the ventral midline more numerous in $C$. townsendi than in B. pterotum larvae. Sequence of photophore development in Ceratoscopelus: $\mathrm{Br}_{2}, \mathrm{Vn}, \mathrm{PLO}, \mathrm{PO}_{5}$, and in B. pterotum: $\mathrm{Br}_{2}$, Dn, $\mathrm{PO}_{5}, \mathrm{PVO}_{1}$.

Larvae of $C$. townsendi differ from Bolinichthys mainly in the smaller and less rounded eyes in Ceratoscopelus (especially in small larvae).

\section{Genus Diaphus}

The genus Diaphus is the most speciose among the lanternfish of the Agulhas region. Identification of larval stages of Diaphus species (Moser and Ahlstrom 1974; 1996; Moser et al. 1984; Olivar and Beckley 1995) depends on slight morphological and pigmentation differences. Olivar and Beckley (1995) identified and described the posflexion lar- 
vae of Diaphus diadematus, the larvae of D. mollis, and the larvae of another Diaphus, possibly Diaphus brachycephalus or D. richardsoni, from samples collected on the three cruises. Furthermore, other "types" of Diaphus larvae named A, B, C (Olivar and Beckley 1994a) where also differentiated but not identified.

\section{Genus Lampadena}

Adults of three species of Lampadena have been recorded in the Agulhas Current region: L. luminosa, L. notialis and L. speculigera (Hulley 1984a). L. notialis is a species of the "South temperate pattern" and was represented by only one specimen. $L$. speculigera also has a "Temperate pattern". A "Tropical" pattern is characteristic of L. luminosa (Hulley 1992).
Lampadena luminosa (Garman, 1899)

(Figs. 11, 12)

Counts: D 14-15, A 13-15, P 15-17, GR 4+1+810.

Larvae were captured on all three cruises but not in areas where colder waters were present (Olivar and Beckley 1994a). In general, larger larvae did not occur at the most inshore stations. We collected a total of 44 postflexion larvae and 147 preflexion and flexion larvae, ranging from 3.8 to 12.4 $\mathrm{mm}$ BL. Identification of larvae of this species was based on the similarity of our largest larva (12.4 $\mathrm{mm})$ and a $12.8 \mathrm{~mm}$ larva described by Moser and Ahlstrom (1974), and by the gill raker count of our specimen. Smaller stages were compared in a continuous graded series of development from this larger larva to $3.8 \mathrm{~mm}$.

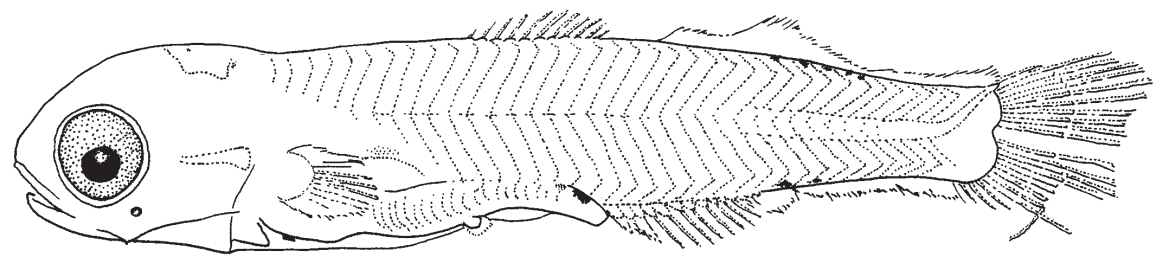

$7.5 \mathrm{~mm} \mathrm{BL}$
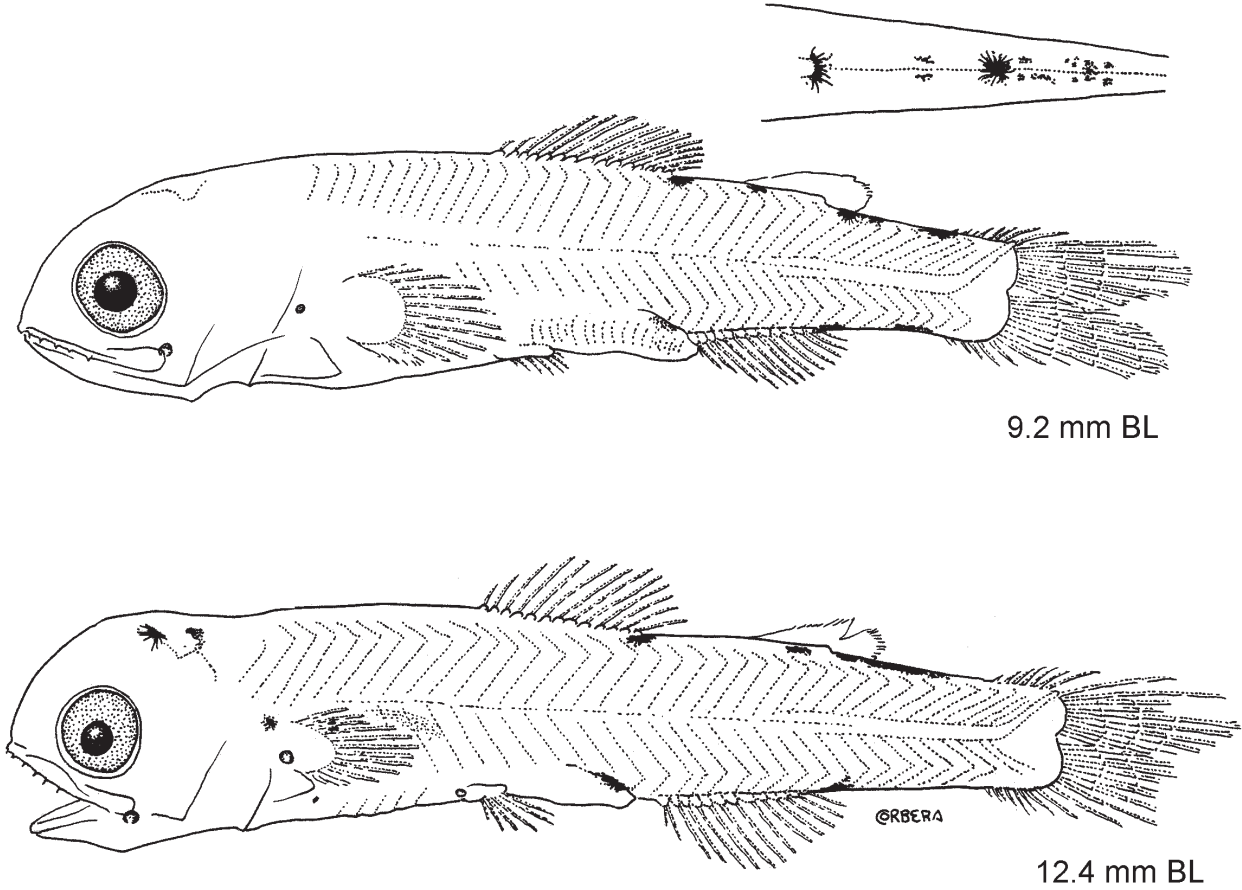

FIG. 12. - Postflexion stages of Lampadena luminosa from the Agulhas current region: $7.5 \mathrm{~mm}, 9.2 \mathrm{~mm}$, dorsal and lateral view, and $12.4 \mathrm{~mm}$. ICICMB 188/AGU. 


\section{Morphology}

Larvae slender during all stages of development (BDP $<23 \%$ of $\mathrm{BL}$ ), but especially during preflexion stages (BDP 11-14\% BL); gut straight, extending to midpoint of body in early larvae $(3.8 \mathrm{~mm})$ and beyond midpoint ( $60 \%$ of BL) in larger larvae; eyes round in all the larval stages; notochord flexion begins around $5.5 \mathrm{~mm}$ and the urostyle is flexed at $6.0 \mathrm{~mm}$.

\section{Pigmentation}

Pigmentation varies gradually during development; pigmentation over gas bladder in all sizes; internal pigment on anterior part of the gut (in front of liver) barely visible in largest larvae but distinct in larvae $<7.5 \mathrm{~mm}$, and generally more apparent in preflexion larvae; postanal pigmentation consists of a series of midventral tail melanophores (ca. 18-20) in preflexion stages that disappear gradually during flexion and fuse to form one or two large melanophores posterior to anal fin; dorsal pigmentation on tail appears in preflexion stages at $c a .5 \mathrm{~mm}$ and consists of a double line of pigment extending along 5 or 6 myomeres; in postflexion stages dorsal pigmentation consists of several melanophores located from dorsal fin insertion to caudal peduncle; pigmentation above brain distinct in largest larvae $(12.4 \mathrm{~mm})$, but indistinct or absent in earlier stages; pigmentation absent in otic region.

\section{Fins and photophore development}

The caudal fin forms first, followed by the anal, dorsal, pectoral and pelvic fins; the $\mathrm{Br}_{2}$ photophore appears at $c a .6 \mathrm{~mm} \mathrm{BL}$, the PLO at $c a .10 \mathrm{~mm}$, and the $\mathrm{PO}_{5}$ at $c a .12 .5 \mathrm{~mm}$.

\section{Meristic characters}

Myomere count 36-37; gill raker count 3 or $4+1+6$ in the $12.4 \mathrm{~mm}$ larva.

\section{Discussion of the identification of Lampadena larvae}

The $12.4 \mathrm{~mm}$ larva from the Agulhas region is very similar to the $12.8 \mathrm{~mm} \mathrm{~L}$. luminosa described by Moser and Ahlstrom (1974) and the postflexion larvae described by Ozawa (1986). All have the $\mathrm{Br}_{2}$, $\mathrm{PLO}, \mathrm{PO}_{5}$ photophores well formed dorsal and anal rays. One difference is the presence of occipital pigmentation and the pigmentation anterior to the pectoral bases present in the $12.4 \mathrm{~mm}$ larva from the Agulhas region and the absence of this pigmentation in the larvae illustrated by the other authors. Gill raker counts eliminated the possibility that our larva belonged to L. notialis or L. speculigera, two other Lampadena species present in the region.

Pigmentation of preflexion and flexion stages of our larvae differs somewhat from that described by Ozawa (1986). His smallest L. luminosa $(4.8 \mathrm{~mm})$ already have dorsal pigmentation and lack the row of melanophores in the ventral midline of the tail. This may be due to shrinkage by preservation in his specimens. The preflexion larva of L. luminosa illustrated by Miller et al. (1979) did not resemble those of Ozawa (1986) nor the smallest larvae described here and is not L. luminosa. It may be another species of Lampadena.

\section{Comparative remarks}

The smallest larvae are similar to those of Diaphus spp. and Ceratoscopelus spp. Ventral tail pigmentation differs from that of Diaphus larvae. In Lampadena larvae there is one melanophore at each myoseptum whereas in Diaphus there are generally fewer ventral tail melanophores and they are less evently spaced. Also, in Diaphus there is a small melanophore at the base of the caudal fin, well separated from the posteriormost melanophore in the ventral series. The main difference in preflexion stages of $L$. luminosa and $C$. townsendi is the absence of pigmentation on the isthmus and the smaller number of postanal melanophores (6-11) in the latter. Diagnostic characters for the larger larvae are: 1) dorsal pigmentation present on the tail in $L$. luminosa but not present in $C$. townsendi nor in $B$. pterotum; and 2) sequence of photophore development (L. luminosa, $\mathrm{Br}_{2}, \mathrm{PLO}, \mathrm{PO}_{5}$; B. pterotum, $\mathrm{Br}_{2}$, $\mathrm{Dn}, \mathrm{PO}_{5} ;$ C. townsendi, $\mathrm{Br}_{2}, \mathrm{Vn}, \mathrm{PLO}, \mathrm{PO}_{5}$ ).

\section{Genus Lampanyctus}

Adults of ten species of Lampanyctus are found in the area (Hulley, 1984a). Larvae of Lampanyctus lepidolychnus were the most abundant during the three cruises, followed by L. alatus. Other species of Lampanyctus which also appeared in the cruises were L. achirus, L. ater, L. nobilis and L. pusillus.

Descriptions of the larvae of this genus collected in the Agulhas region are given by Olivar and Beckley (1997). Larvae of Lampanyctus have some resemblance to those of Notoscopelus which have smaller teeth in the upper jaw, pigmentation on the dorsal surface of the gas bladder, and an early development of the $\mathrm{PO}_{5}$ photophore (Moser and Ahlstrom 1974, 1996). 


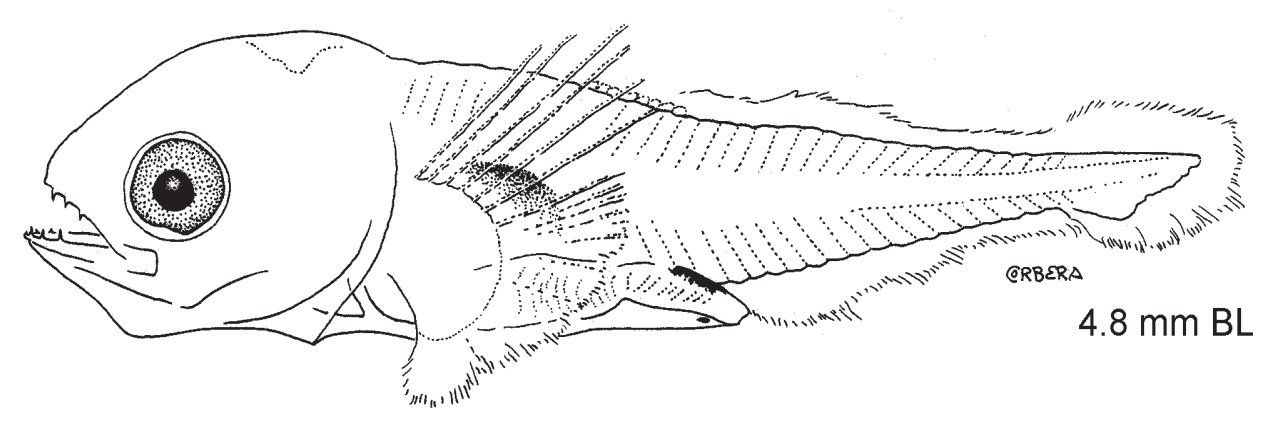

FIG. 13. - Larva of Lobianchia dofleini from the Agulhas current region: $4.8 \mathrm{~mm}$. ICICMB 190/AGU.

\section{Genus Lobianchia}

Mature adults of the tropical $L$. dofleini and $L$. gemellari have been collected in the Agulhas current region (Hulley 1984a).

Lobianchia dofleini (Zugmayer, 1911)

(Fig. 13)

Counts: D 15-17, A 13-15, P 10-13, GR 4$6+1+12-15$.

Larvae of this species were described by Tåning (1918); Dekhnik and Sinyukova (1966); Moser and Ahlstrom (1974) and Berdar and Cavaliere (1975). The single larva collected in the present study has pigmentation only on the peritoneum above the air bladder and the eye is small and round with no choroid tissue. Eyes in larger larvae appear to have an elongate shape due to the presence of the squarish mass of choroid tissue, but at this stage they are still round and lack choroid tissue.

\section{Lobianchia gemellarii (Cocco, 1838)}

(Fig. 14)

Counts: D 16-18, A 13-15, P 11-13, GR 47+1+10-15, vertebrae 34-35.

Larvae appeared during the three cruises, being most abundant in May/June 1990. These larvae were relatively common throughout the study region, although their concentrations were low. Total larvae examined: 99, 3.8-8.4 mm. Identification was based on the descriptions of Cavalieri and Berdar (1976); Moser and Ahlstrom (1974, 1996) and Ozawa (1986).

\section{Diagnostic characters}

Broad head with large eyes; pectoral fins with the upper rays elongated, and the lower part mem- branous; strong pigmentation on the anterior gut region and at the base of pectoral fin; one melanophore in the midline of the body posterior to anal fin.

\section{Comparative remarks}

L. gemellarii larvae have larger eyes and a more pigmented body than L. dofleini. In flexion stages and postflexion stages, the shape of the pectoral fin differentiates these two species: in $L$. gemellari there is a conspicuous difference between upper and lower part of the pectoral fin whereas in L. dofleini the lower pectoral rays develop subequally with the produced upper rays (Moser and Ahlstrom 1974).

\section{Notolychnus valdiviae (Brauer, 1904)}

This species is generally widely distributed throughout the warmer waters of all three oceans (Hulley 1981). Counts: D 10-12, A 12-14, P 11-14, GR 2+1+7-8.

Larvae occurred on the three cruises, mainly north of Mbashe. Total larvae examined: 59, ca. 4$8.6 \mathrm{~mm}$. Larvae were identified using the descriptions of Tåning 1918; Moser and Ahlstrom (1974, 1996) and Shiganova (1975).

\section{Diagnostic characters}

Short gut (PAL $<50 \%$ BL); oval eyes; discrete melanophores on the ventral midline of the tail and mid-hypural pigmentation.

\section{Genus Notoscopelus}

(Hulley 1984a) collected the two tropical species, Notoscopelus caudispinosus and N. resplendens, in this region, although all of his $N$. caudispinosus specimens were immature. 

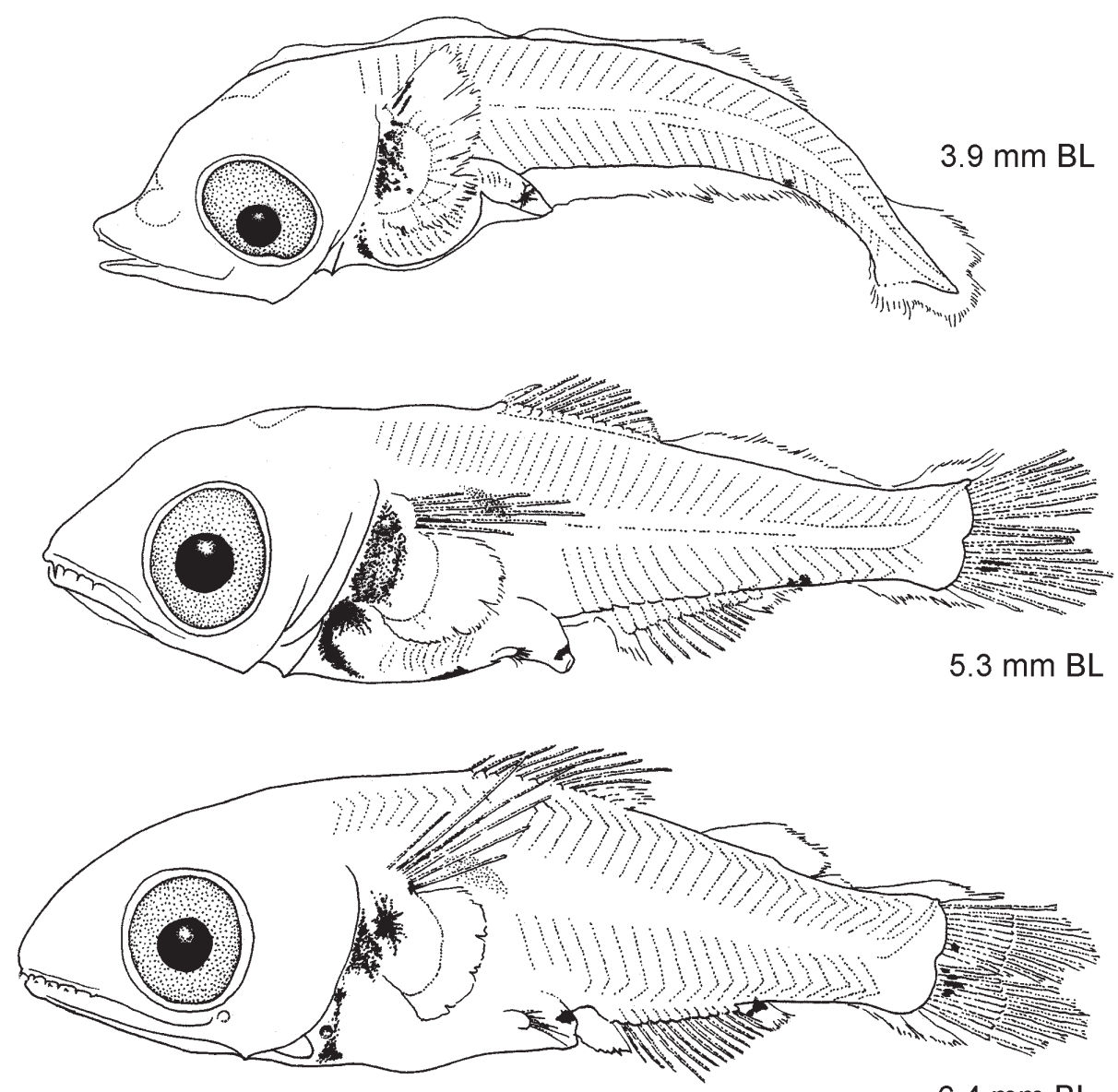

$6.4 \mathrm{~mm} \mathrm{BL}$

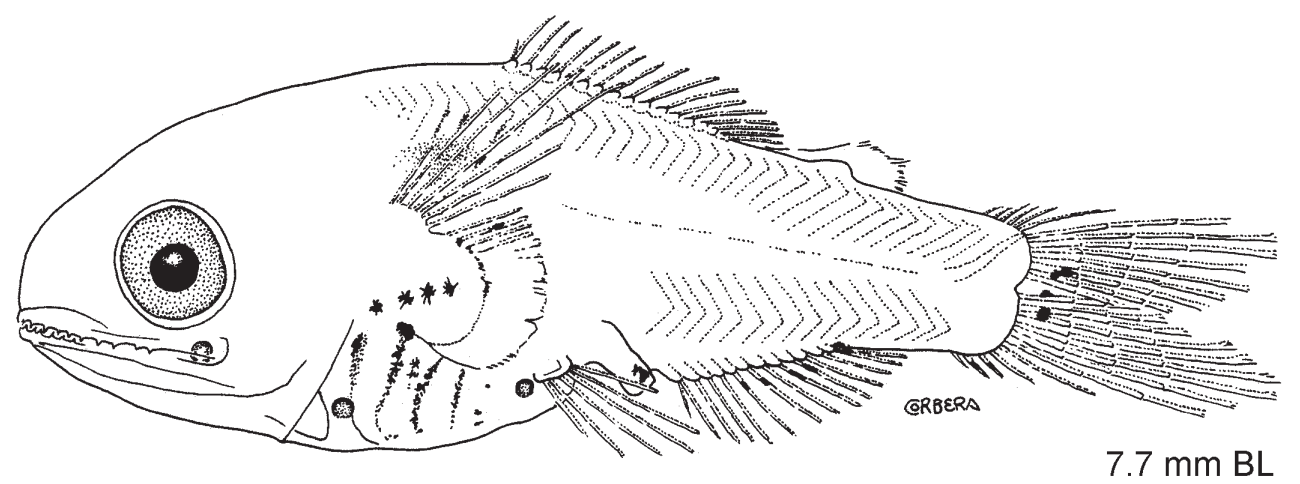

FIG. 14. - Developmental stages of Lobianchia gemellarii from the Agulhas current region: $3.9 \mathrm{~mm}, 5.3 \mathrm{~mm}, 6.4 \mathrm{~mm}$ and $7.7 \mathrm{~mm}$. ICICMB 191/AGU.

\section{Notoscopelus caudispinosus (Johnson, 1863)} (Fig. 15)

Counts: D 24-27, A 19-21, P 11-13, GR 4+1+810.

Larvae of this species occurred only during the May/June 1990 cruise, throughout the study region. Total larvae examined: 57 , all in preflexion and flexion stages, 3.6-4.8 mm BL. Identification was based on the descriptions of Ozawa (1986).

\section{Morphology}

Eyes large and round in preflexion and flexion larvae (ED 16\% BL); anterior part of the body relatively deep (BDP 30\% BL); gut short (PAL <50\% $\mathrm{BL}$ in preflexion larvae).

\section{Pigmentation}

Pigmented dorsal surface of the gas bladder useful for identification to genus; melanophores present on hindbrain and forebrain, and conspicuous pigmenta- 

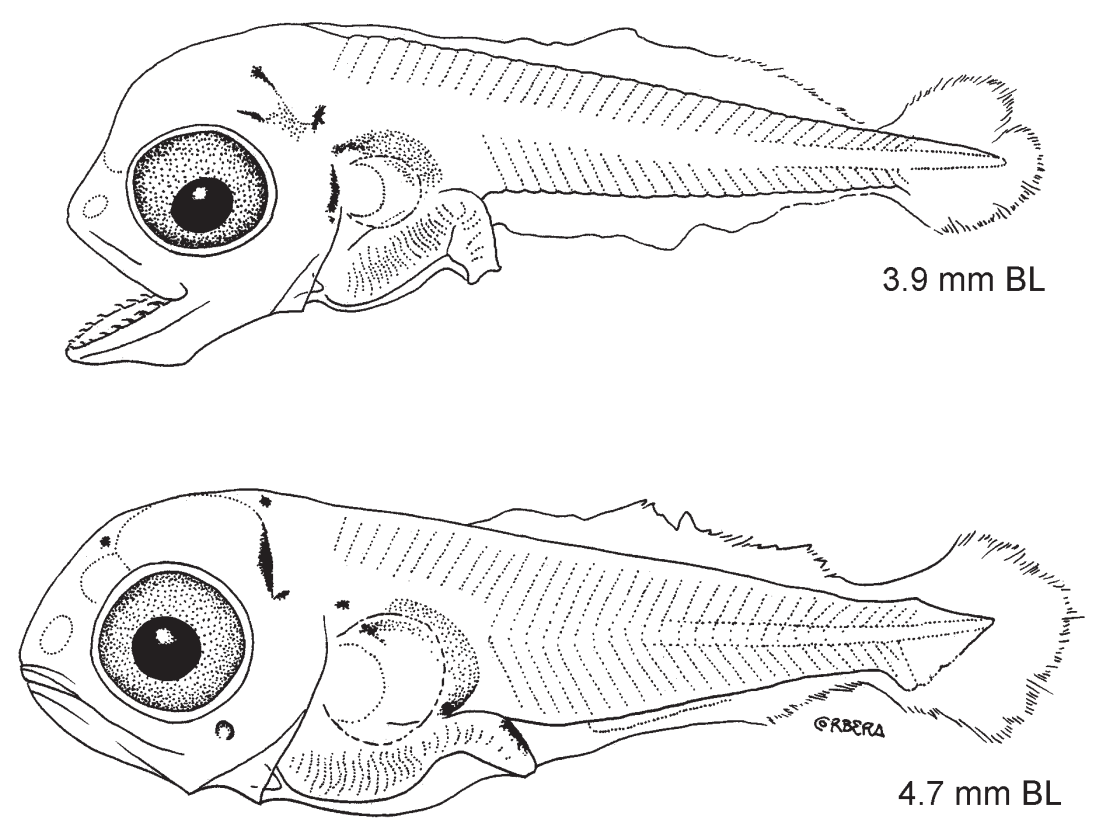

FIG. 15. - Developmental stages of Notoscopelus caudispinosus from the Agulhas current region: $3.9 \mathrm{~mm}$ and 4.7 mm. ICICMB 192/AGU.

tion visible near otic region; no pigment present on jaw tips nor on tail; free terminal section of gut pigmented in flexion larvae but not in preflexion ones.

Photophore development

$\mathrm{Br}_{2}$ already visible in $4 \mathrm{~mm}$ larvae.

Notoscopelus resplendens (Richardson, 1845)

Counts: D 21-24, A 17-20, P 11-13, GR 5$7+1+12-15$.

Only 10 larvae of this species, from ca. 3.5 to 7 mm BL, occurred in May/June 1990 and October 1990 cruises. They were identified using the descriptions of Moser and Ahlstrom $(1972,1996)$ and Ozawa (1986).

\section{Diagnostic characters}

These larvae may be differentiated from those of N. caudispinosus by the smaller eyes (ED $<12 \%$ $\mathrm{BL})$. The dorsal and ventral pigmentation on the tail and the pigmentation on the jaw tips in N. resplendens are the main pigmentation features that differentiate them from $N$. caudispinosus.

\section{Scopelopsis multipunctatus Brauer, 1906}

(Fig. 16)

Adults of the subtropical Scopelopsis multipunctatus are relatively abundant in the study region
(Hulley 1984a). Counts: D 20-25, A 23-27, P 10-12, GR 7-9+1+14-17.

Larvae of this species were very abundant during the May/June 1990 survey but did not appear in the two other cruises. They were distributed all along the study area, with highest densities at the most offshore stations. Total larvae examined: 1172, 2.5-10.5 mm BL. Identification was based on Moser and Ahlstrom (1972). They ranged from preflexion to postflexion stages. Two preflexion stages of these larvae (4.2 and $5.7 \mathrm{~mm} \mathrm{BL}$ ) are depicted here because in the description of Moser and Ahlstrom (1972) the smallest larvae are in flexion stages and we found some differences in preflexion stages compared with later larval stages. The number of melanophores on the ventral midline of the tail is a little higher (six instead of five). In some larvae these melanophores are not punctate, but linear, and sometimes form a more or less continuous line of pigment. Otherwise the characters conform to those discussed in Moser and Ahlstrom (1972).

\section{Diagnostic characters}

Short gut (PAL $<50 \%$ BL); a prominent melanophore at the nape; conspicuous pigmentation above the developing gas bladder; lateral teeth of the lower jaw curved anteriad. Morphology of these larvae resembles that of $N$. valdiviae, but the larvae may be differentiated by the larger and more round eyes, the pigmentation on the nape in S. multipunctatus, and the teeth. 


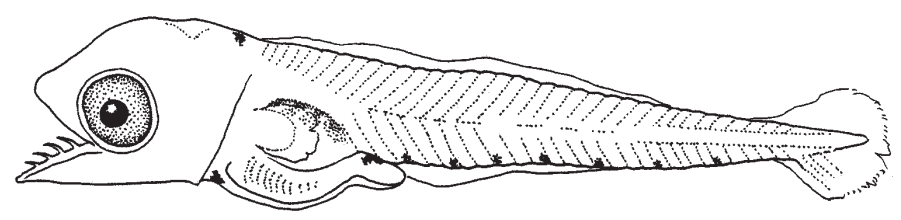

$4.2 \mathrm{~mm} \mathrm{BL}$

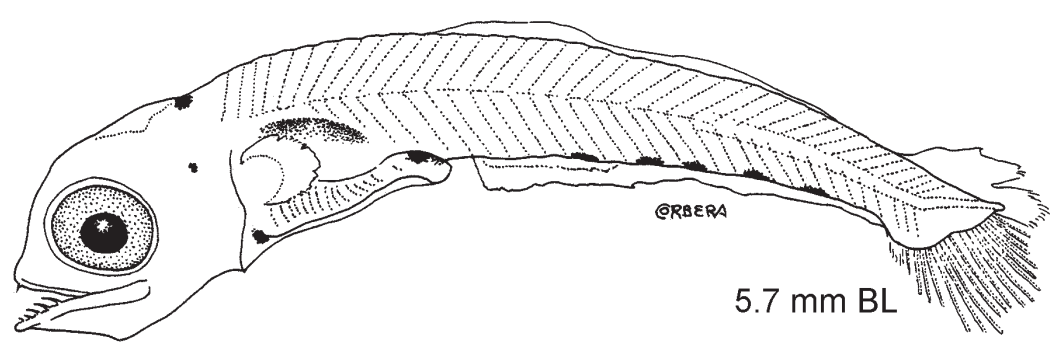

FIG. 16. - Developmental stages of Scopelopsis multipuctatus from the Agulhas current region: $4.2 \mathrm{~mm}$ and 5.7 mm. ICICMB 193/AGU.

Triphoturus nigrescens (Brauer, 1904) (Fig. 17)

No sexually mature specimens of this species have been found in the area (Hulley 1984a). Counts: D 13-15, A 16-18, P 8-10, GR 2-4+1+7-10.

Larvae were more frequent in the October 1990 survey than in the other two surveys. The southernmost location for these larvae was East London; they were most abundant offshore of the $200 \mathrm{~m}$ isobath. Total larvae collected: 32, 4.1-11.3 mm BL. Larvae were identified with the descriptions of Moser (1981); Belyanina (1986) and Moser and Ahlstrom (1996).

\section{Morphology}

Larvae moderately slender (BDP 58\% BL in preflexion larvae and $23 \% \mathrm{BL}$ in postflexion larvae);
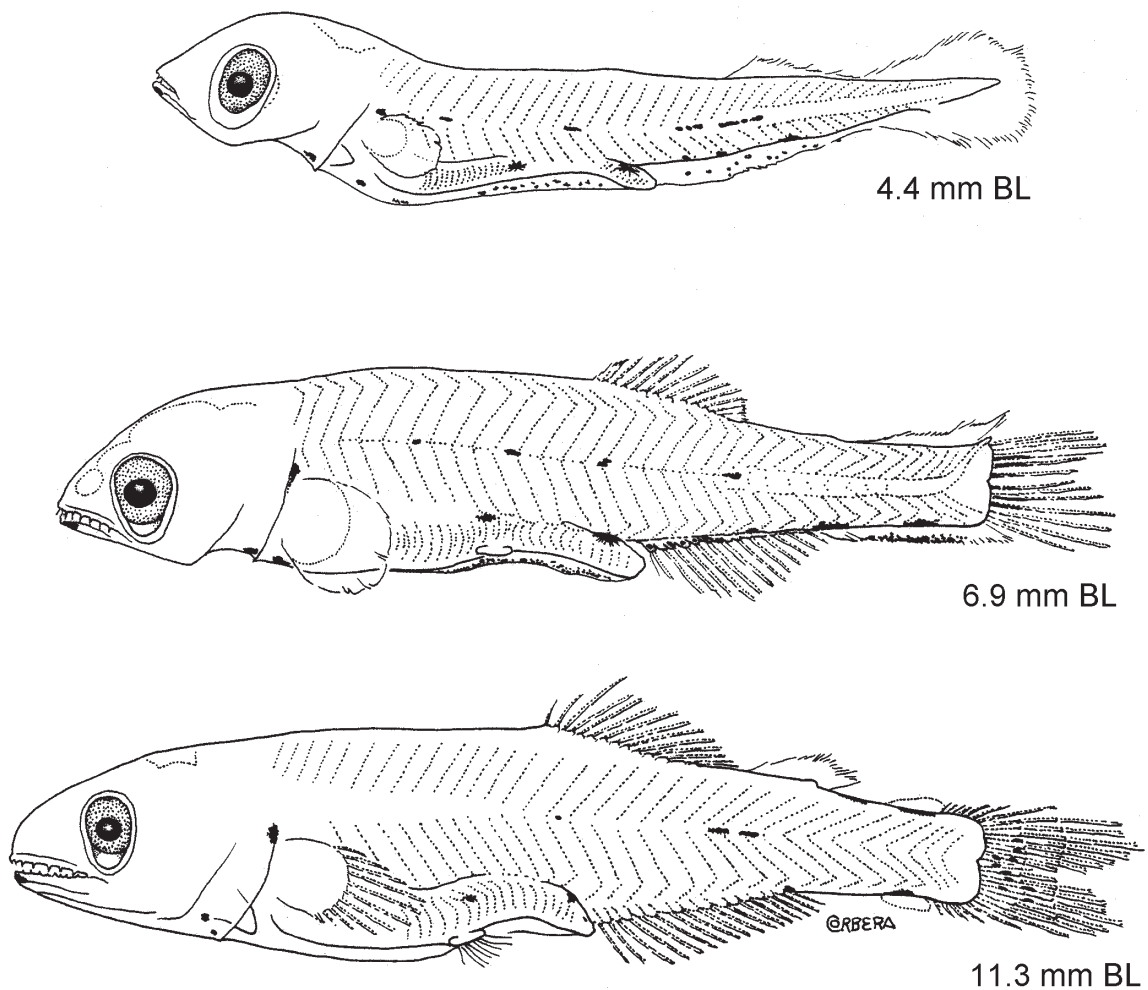

FIG. 17. - Developmental stages of Triphoturus nigrescens from the Agulhas current region: $4.4 \mathrm{~mm}, 6.9 \mathrm{~mm}$ and 11.3 mm. ICICMB 195/AGU. 
gut extends to $c a$. $60 \%$ of $\mathrm{BL}$; choroid tissue visible at the base of the eyes in flexion and postflexion stages; notochord flexion begins around $5.5 \mathrm{~mm}$ and the notochord is flexed at $6.5 \mathrm{~mm}$.

\section{Pigmentation}

Conspicuous pigment dashes on the lateral midline of the body, becoming scanty in the largest larvae $(11.3 \mathrm{~mm})$; melanophores visible at tip of lower jaw, isthmus, lateral walls of midgut and anus and on ventral midline of body.

\section{Photophore development}

No photophores present in the largest larva examined.

\section{ACKNOWLEDGEMENTS}

The authors wish to thank Dr. P.A. Hulley of the South African Museum, Cape Town, and Mr. P. Rubiés of the Institut de Ciències del Mar (ICM) Barcelona, for the advice and information provided, and to Mr. J. Corbera who drew the larvae. The comments by J. Leis are greately appreciated.

\section{REFERENCES}

Badcock, J. and N.R. Merrett. - 1976. Midwater fishes in the eastern North Atlantic. 1. Vertical distribution and associated biology in $30^{\circ} \mathrm{N}, 23^{\circ} \mathrm{W}$, with developmental notes on certain myctophids. Prog. Oceanogr. 7: 3-58.

Beckley, L.E. and R.C. Van Ballegooyen. - 1992. Oceanographic conditions during three ichthyoplankton surveys of the Agulhas current in 1990/91. In: A.I.L. Payne, K.H. Brink, K.H. Mann. and R. Hilborn (eds.), Benguela Trophic Functioning. S. Afr. J. mar. Sci. 12: 83-93.

Belyanina, T.N. - 1986. Ichthyoplankton of some seamounts of the northwestern Indian Ocean with description of successive larval stages of development of Triphoturus nigrescens Brauer and 3 forms of Diaphus (Fam. Myctophidae). Tr. Inst. Okeanol. Akad, Nauk SSSR. 116: 73-84.

Berdar, A and A. Cavaliere. - 1975. Stadi larvali e postlarvali di mictofidi: Lobianchia dofleini Zug. Atti Soc. Pelor. Sci. Fis. Mat. Nat. 21: 115-122.

Berdar, A. and A. Cavaliere. - 1979. Stadi larvali e postlarvali di mictofidi: Hygophum hygomi (Lütken). Mem. Biol. Mar. Ocean. 9 (6): 167-173.

Bourret, P. - 1985. Poissons Téléostéens: Gonostomatidae, Sternoptychidae et Myctophidae (MUSORTOM II). Mem. Mus. Nat. Hist. Nat. sér. A, Zool. 133: 55-82.

Cavaliere, A. and A. Berdar. - 1976. Stadi larvali e postlarvali di mictofidi: Lobianchia gemellarii Cocco. Mem. Biol. Mar. Ocean. 6 (5): 175-182.

Dalpadado, P. - 1988. Reproductive biology of the lanternfish Benthosema pterotum from the Indian Ocean. Mar. Biol. 98: 307-316.

Dekhnik, T.V. and V.I. Sinyukova. - 1966. Distribution of pelagic fish eggs and larvae in the Mediterranean Sea. Part II. On the reproduction and ecology of larvae in Mediterranean Myctophidae, In: Studies on plankton of Southern Seas. Nauka, Moskow: 82-108. (In Russian, English translation 55. U.S. Department of Commercial Fisheries).

Fahay, M.P. 1983. Guide to the early stages of marine fishes occur- ring in the western North Atlantic Ocean, Cape Hattaras to the southern Scotian Shelf. J. Northwest Atl. Fish. Sci. 4:1-423.

Fujii, E.- 1984. Myctophidae. In: H. Masuda, K. Amaoka, C. Araga, $\mathrm{T}$. Uyeno, and T. Yoshino (eds.), The fishes of the Japanese Archipelago. Tokai ljniv. Press, Tokyo: 64-75

Hulley, P.A. - 1981. Results of the research cruise of FRV "Walter Herwig" to South America. Family Myctophidae (Osteichthyes, Myctophiformes). Archiv für Fischereiwissenschaft 31(1):1-300.

Hulley, P.A. - 1984a. The South African Museum's Meiring Naude cruises Part 14 Family Myctophidae (Osteichthyes, Myctophiformes). Ann. S. Afr. Mus. 93(2): 53-96.

Hulley, P.A. - 1984b. Myctophidae. In: P.J.P. Whitehead, M.-L. Bauchot, J.-C. Hureau, J. Nielsen and E. Tortonese (eds.), Fishes of the North-eastern Atlantic and the Mediterranean. UNESCO 1: 429-483.

Hulley, P.A. - 1986. Family No. 86: Myctophidae. In: M.M. smith and P.C. Heemstra (eds.): Smiths' Sea Fishes. Springer-Verlag, Berlin: 282-321.

Hulley, P.A. - 1992. Upper-slope distributions of oceanic lanternfishes (family: Myctophidae). Mar. Biol., 114(3): 365-383.

Kendall, A.W., E.H. Ahlstrom and H.G. Moser. - 1984. Early life history stages of fihes and their characters. In: H. G. Moser, W. J. Richards, D.M. Cohen, M.P. Fahay, A.W. Jr. Kendall and S.L. Richardson (eds.): Ontogeny and Systematics of Fishes, American Society of Ichthyologists and Herpetologist. Special Publication Number 1: 11-22. Gainesville, Florida.

Leis, J.M. and D.S. Rennis. - 1983. The larvae of Indo-Pacific coral reef fishes. New South Wales Univ. Press, Kensington. $269 \mathrm{pp}$.

Leis, J.M. and T. Trnski. - 1989. The larvae of Indo-Pacific shorefishes. New South Wales Univ. Press, Kensington. 371 pp.

Matarese, A.C., A.W. Kendall, Jr., D.M. Blood, and B.M. Vinter. 1989. Laboratory guide to early life history stages of northeast Pacific fishes. U.S. Dep. Commer. NOAA Tech. Rep. NMFS 80. $652 \mathrm{pp}$.

Miller, J.M., W. Watson and J.M. Leis. - 1979. An Atlas of Near Shore Marine Fish Larvae of the Hawaiian Islands. Miscellaneous Report, Hawaii Sea Grant College Program, Honolulu. MR-80-02: $179 \mathrm{pp}$

Moser, H.G. - 1981. Morphological and functional aspects of marine fish larvae. In: R. Lasker (ed.), Marine fish larvae. Morphology, ecology, and relation to fisheries, pp. 89-131. Univ. Wash. Press. Seattle.

Moser, H.G. (ed.) - 1996. The early stages of fishes in the California Current region. CalCOFI Atlas, 33: 1-1504.

Moser, H.G. and E.H. Ahlstrom. - 1970. Development of lanternfishes (family Myctophidae) in the California Current. Part I. Species with narrow-eyed larvae. Nat. Hist. Mus. Los Ang. Cty. Sci. Bull., 7: 1-145.

Moser, H.G. and E.H. Ahlstrom. - 1972. Development of lanternfish, Scopelopsis multipunctatus Brauer 1906, with a discussion of its phylogenetic position in the family Myctophidae and its role in a proposed mechanism for the evolution of photophore patterns in lanternfishes. Fish. Bull. U.S 70: 541-564.

Moser, H.G. and E.H. Ahlstrom. - 1974. Role of larval stages in systematic investigations of marine teleosts: the Myctophidae, acase study. Fish. Bull. U.S. 72: 391-413.

Moser, H.G. and E.H. Ahlstrom. - 1996. Myctophidae: Lanternfihes. In: H. G. Moser (ed.), The early stages of fishes in the California current region. Calcofi Atlas 33: 387-475.

Moser, H.G., E.H. Ahlstrom and J.R. Paxton. - 1984. Myctophidae: Development. In: H.G. Moser, W.J. Richards, D.M. Cohen, M.P. Fahay, A.W. Jr. Kendall and S.L. Richardson (eds.), Ontogeny and Systematics of Fishes, pp. 218-239. American Society of Ichthyologists and Herpetologist. Special Publication Number 1. Gainesville, Florida.

Nafpaktitis, B.G. - 1978. Systematics and distribution of lanternfish of the genera Lobianchia and Diaphus (Myctophidae) in the Indian Ocean. Nat. Hist. Mus. Los Ang. Cty. Sci. Bull., 30: 1-92.

Nafpaktitis, B.G., R.H. Backus, J.E. Craddock, R.L. Haedrich, B.H. Robison and C. Karnella. - 1977. Family Myctophidae. In: H.B. Bigelow (ed.), Fishes of the Western North Atlantic. Memoir Sears Foundation for Marine Research 1(4): 13-265.

Nafpaktitis, B.G. and M. Nafpaktitis. - 1969. Lanternfishes (Family Myctophidae) collected during cruises 3 and 6 of the $\mathrm{R} / V$ Anton Bruun in the Indian Ocean. Nat. Hist. Mus. Los Ang. Cty. Sci. Bull., 5: 1-79. 
Neira, F.J., A.G. Miskiewicz and T. Trnski.- 1998. Larvae of Temperate Australian Fishes. Laboratory Guide for Larval Fish Identification. Univ. Western Australia Press. Nedlands. 474 pp.

Okiyama, M. (ed.) - 1988. An atlas of the early, stage fishes in Japan. Tokai Univ. Press, Tokyo. 1154 pp. [in Japanese].

Olivar, M.P. and L.E. Beckley. - 1994a. Influence of the Agulhas Current on the distribution of lanternfish larvae off the South East coast of Africa. J. Plankton Res. 16 (12):1759-1780

Olivar, M.P. and L.E. Beckley. - 1994b. Investigations on the occurrence of larvae of Symbolophorus species (Myctophidae) off Southern Africa. S. Afr. J. mar. Sci. 14: 349-359.

Olivar, M.P. and L.E. Beckley. - 1995. Early development of Diaphus spp. (Pisces: Myctophydae) of the Agulhas Current. $S$. Afr. J. mar. Sci. 16: 129-139.

Olivar, M.P. and L.E. Beckley. - 1997. Larval development of Lampanyctus species (Pisces: Myctophidae) from the SW Indian Ocean, and species groups based on larval characters. Bull. Mar. Sci. 60(1): 47-65.

Olivar, M.P. and J.M. Fortuño.- 1991. Guide to the ichthyoplankton of the southeast Atlantic (Benguela Current region). Sci. Mar. 55: $1-383$.

Olivar, M.P. and I. Palomera. - 1994. Ontogeny and distribution of Hygophum benoiti (Pisces, Myctophidae) of the Northwestern Mediterranean. J. Plankton Res 16(8): 977-991.

Ozawa, T. - 1986. Early life history of the family Myctophidae in the ocean off southern Japan. In: T. Ozawa (ed.), Studies on the oceanic ichthyoplankton in the western North Pacific, pp. 114188. Kyushu University Press, Fukuoka, Japan.

Pertseva-Ostroumova, T.A. - 1974. New data on lanternfish larvae (Myctophidae, Pisces) with oval eyes from the Indian and Pacific Oceans. Tr. Inst. Okeanol. Akad. Nauk. SSSR, 96: 77 142 (In Russian).

Russell, F.S. - 1976. The eggs and planktonic stages of British marine fishes. Academic Press, London. 524 pp.

Shiganova, T.A. - 1975. Postembryonic development of Notolychnus valdiviae (Brauer, 1904) Myctophidae, Osteichthyes Tr. Inst. Okeanol. Akad. Nauk. SSSR, 101: 75-87.

Shiganova, T.A. - 1977. Larvae and juveniles of the lanternfishes (Myetophidae, Pisces) of the Atlantic Ocean. Tr. lnst .Okeanol. Akad. Nauk SSSR, 109:42-112 [in Russian].

Tåning, A.V. - 1918. Mediterranean Scopelidae (Saurus, Aulopus, Cholorphthalmus, and Myctophum). Rep. Danish. Oceanogr. Exped. Mediterr., 2. Biology. (A.7): 1-154.

Tsokur, A.G. - 1982 The larvae of Benthosema pterota (Alcock, 1891) Myctophidae, from the Arabian Sea. J. Ichthyol. 3: 3853.

Wisner, R.L. - 1976. The taxonomy and distribution of lanternfishes (family Myctophidae) of the eastern Pacific Ocean. Navy Ocean Research and Development Activity Rep. 3: 1-229.

Scient. ed.: P. Abelló 